\title{
Voting at the dawn of a global pandemic
}

\author{
Arndt Leininger and Max Schaub*
}

\author{
This version: April 2020
}

\begin{abstract}
What is the impact of a global health crisis on political behavior? We study the effect of the COVID-19 pandemic on electoral choice based on the case of Germany, one of the countries most heavily affected by the crisis. Our data come from the German state of Bavaria, where local elections were held right at the beginning of the pandemic. The elections took place early during the outbreak when there was still substantial variation in the extent to which individual counties and municipalities were affected by the outbreak. This variation provides a unique opportunity to study the causal impact of an event that would shortly after grow into an allencompassing epidemic. We provide evidence that shows that the disease spread across the state in a mostly haphazard fashion. This lack of a discernible pattern coupled with within-county estimation of effects and a difference-in-differences strategy allow us to causally asses the effect of the spreading of the virus on electoral outcomes. Our results show that the crisis strongly and consistently benefited the dominant regional party, the CSU, and its candidates. For 3 known cases per 100,000 inhabitants, vote shares increased by about 4 percent. We explain our findings with a strategic-alignment mechanism, whereby voters vote into power candidates that they deem most likely to be able to solicit support from higher levels of government. Our findings emphasize the merit of forward-looking theories of voting and provide insights on the functioning of democracy during times of crisis.
\end{abstract}

Keywords: COVID-19; Voting; Elections; Incumbency effect; Germany.

*Arndt Leininger (arndt.leininger@uni-konstanz.de) is interim professor for survey research at the University of Konstanz, Box 85, 78457 Konstanz, Germany; Max Schaub (max.schaub@wzb.eu) is Research Fellow at the Berlin Social Science Center (WZB), Reichpietschufer 50, 10785 Berlin, Germany. We thank Daniel Bischof, Martin Gross, Davide Morisi, and Julia Schulte-Cloos for their feedback. We are also grateful to Philipp David Pries and the team of the Ippen-Digital-Zentralredaktion for sharing their data on the mayoral elections with us. Lilia Götz and Gizem Ünsal provided excellent research assistance. 


\section{Introduction}

The spread of the coronavirus disease (COVID-19) presents itself in many countries as a natural disaster of unprecedented scale. What are the implications for politics? The COVID-19 pandemic interferes not just with social and cultural life, sporting events, and of course, the economy; it also affects politics. Unlike sporting events, elections cannot be canceled or postponed as easily. While Israel voted during the onset of the epidemic in early March with special polling stations crewed by medical staff in protective gear for quarantined voters, in the USA, some states had to cancel primary elections. As of yet, the implications of the pandemic for the presidential elections to be held in November are unclear. To shed light on the implications of holding elections during a global crisis, we study recent statewide elections to local councils and mayoralties in Germany's most prosperous state Bavaria. These elections took place amidst the onset of the pandemic caused by the spread of the virus SARS-CoV-2. In this paper, we show that, even in the early stages of the pandemic, the spread of the disease did influence citizens' voting behavior.

Political scientists have long discussed the electoral implications of external events, ranging from rainfall on election day (Gomez et al., 2007; Arnold and Freier, 2016), over terrorism (Berrebi and Klor, 2008; Montalvo, 2011) to natural disasters (Abney and Hill, 1966; Bechtel and Hainmueller, 2011; Carlin et al., 2013) and to outright idiosyncratic events such as sporting competitions (Healy et al., 2010). The precise electoral effects of such events remain unclear, however. Three different theoretical perspectives can be distinguished.

A first strand of literature emphasizes the emotional, spontaneous reaction to such events. One common reaction to threats to life and safety, especially if the nation as a whole is concerned, is to 'rally round the flag' - to increase support for the incumbent government, and especially incumbents of the political right (Mueller, 1970; Baker and Oneal, 2016; Lambert et al., 2011; Berrebi and Klor, 2008; Getmansky and Zeitzoff, 2014). However, others have argued the exact opposite: due to the negative sentiments they arouse in voters, calamities of all kinds tend to reduce support for the incumbent. Central to this argument is a paper by Achen and Bartels (2012; 2017), where they 
demonstrate a negative relationship between shark attacks and incumbent vote share in US counties in the 1916 presidential elections. They take their results as evidence that voters punish governments at the ballot box for events that leave them insecure and upset-even though they are beyond the government's control.

A second perspective emphasizes that natural disasters provide voters with a rather drastic opportunity to learn about the competence of the incumbent government and to evaluate its performance (Ashworth et al., 2018). These scholars link the electoral reaction to external events back to the literature on retrospective voting (Key, 1966; Fiorina, 1981). In this perspective, the electoral effect will depend on the performance of the government during the crisis. Voters may punish the government in elections in the wake of a disaster if they found the government to be ill-prepared or relief measures inadequate (Cole et al., 2012; Arceneaux and Stein, 2006), or they may choose to reward the government for performing well (Bechtel and Hainmueller, 2011; Gasper and Reeves, 2011).

A third perspective, which we develop in detail, looks at voters as forward-looking decision-makers. While this perspective has been criticized as unrealistic by some (Campbell et al., 1960; Converse, 1964), we argue that in reaction to the onset of a slowmoving natural disaster such as the COVID-19 pandemic, it has merit. Drawing on the literature on presidential coattails (Campbell and Sumners, 1990; Calvert and Ferejohn, 1983; Ferejohn and Calvert, 1984a) and electoral balancing (Erikson and Filippov, 2001; Kern and Hainmueller, 2006), we argue that voters will use the ballot box as an opportunity to align their local incumbents with higher levels of government-in the expectation that this will help them through the crisis.

We investigate the impact of the COVID-19 pandemic by exploiting a unique case: the Bavarian municipal elections of 15 March 2020. In the elections, ten million Bavarians were called to the polls to elect local legislatures and executives. We exploit regional variation in infections-some counties still had no cases, while others already registered dozens-to test whether the pandemic affected voters voting patterns. This variation provides an opportunity to study the causal impact of an event that would shortly after grow into an all-encompassing epidemic. Importantly, the outbreak in Bavaria fed 
itself from a variety of sources. Early cases included business people, holidaymakers, and individuals who had visited relatives in areas of Germany heavily affected by the disease. As a result, the virus started spreading in both rural and urban counties in all parts of the state. A variety of balancing and spatial-econometric tests shows that the pattern of the outbreak was no different from random. This lack of a discernible pattern coupled with within-county estimation of effects and a difference-in-differences strategy allow us to estimate the causal effect of the spreading of the virus on electoral outcomes. Importantly, as the elections took place at the onset of the pandemic, there is little indication that the spread of the virus dominated the elections, let alone wider society or th economy. Hence, we believe that our case credibly provides us with 'excludability' in causal parlance.

Our primary outcome of interest is the vote share obtained by Bavaria's incumbent party, the Christian Social Union (CSU). The Bavarian 'sister-party' of Angela Merkel's Christian Democratic Union (CDU) has led every state government since its founding in 1945 and governs in all but one of Bavaria's 96 counties. However, its dominance has come under pressure in recent years by challengers from both the political left and the political right. Overall, the CSU lost 5.1 percentage points statewide when compared to the last elections. Did the incumbent have to cease votes to its challenger parties under the pressure of the spreading disease or was it, in fact, even able to curtail its losses because of the crisis?

Our findings emphatically support the second perspective: the crisis strongly and consistently benefited the CSU and its candidates. We estimate that for 3 known cases per 100,000 inhabitants, vote shares in the county legislatures increased by about 4 percent. This result is robust to a wide variety of specifications and tests, including differences-in-differences, matching, and inverse-probability weighting. The gains for the incumbent party came at the cost of all other parties, but especially of the political far-right (the AfD). Positive electoral returns of the crisis for the incumbent show up in all types of elections. Besides the county legislatures, mayors of around 2,000 municipalities were up for reelection. Here, being affected by COVID-19 cases increased the probability of holding or retaining office by 17 percent. 
In assessing competing theoretical explanations we find that our results are unlikely to be driven by emotional or evaluative, i.e. backward-looking, mechanisms. On the contrary, we find evidence that voters make their choice prospectively, in anticipation of worse times to come. Our findings, therefore, are best explained by the strategicalignment mechanism, whereby voters vote into power candidates that they deem most likely to be able to solicit support from higher levels of government.

We contribute to the literature on how external events can shape political behavior. Our paper adds to the literature in several ways. First, we uncover an effect on electoral outcomes of a disease that, at the time of writing, is spreading globally. The fact that the elections we are studying took place right at the beginning of the pandemic allows us to study this effect causally before the disease became too widespread to afford any variation. Second, in terms of theory, we outline three competing perspectives, which we subsequently test. Our results demonstrate the merit of a perspective that stresses forward-looking, strategic considerations among voters, which can add to the retrospective perspective that has dominated the literature on political behavior in recent years. Third, our findings also have important practical implications: understanding how voters react to natural disasters, such as the global SARS-CoV-2 pandemic, is vital because voters' reactions shape politicians' incentives on how to govern during and in the aftermath of a crisis as well as to invest in future disaster preparedness (Healy and Malhotra, 2009).

\section{The electoral consequences of a global pandemic}

How should we expect the spread of an infectious disease to affect voting behavior? From the literature, we distilled three different theoretical perspectives that allow us to link the pandemic to electoral outcomes. We refer to these perspectives as the emotional-response, retrospective-voting, and prospective-voting perspectives.

We begin by exploring the possibility that voters react emotionally to the outbreak of the pandemic and then translate these emotions into their voting behavior. The spread of the COVID-19 disease, first and foremost, constitutes a threat to health and safety. In 
this regard, it is similar to other threats like war and terrorism. Indeed, US President Trump, the French President Macron and other world leaders declared their countries to be "at war" with the virus. ${ }^{1}$ The fact that the pandemic originated in China and from here spread to the world may add to giving it the guise of an external threat. From a theoretical perspective, we might, therefore, expect findings of the literature on external (security) threats to apply to the COVID-19 outbreak. Scholars have often noted a 'rally-'round-the-flag' effect during times of international conflicts, whereby incumbent politicians gain in support (Mueller, 1970; Baker and Oneal, 2016; Lambert et al., 2011). Such an effect may also apply to natural disasters (Boittin et al., 2020). Mueller (1970, p. 21) argues that events leading to a rally-'round-the-flag effect "must be international because only developments confronting the nation as a whole are likely to generate a rally round the flag effect" (p. 21), directly involve the whole country and government, and "must be specific, dramatic and sharply focused in order to assure public attention and interest." All of these criteria arguably apply to the global COVID-19 pandemic. We would, therefore, expect a positive effect of COVID-19 exposure on incumbent vote shares. $^{2}$

Other research has qualified this claim. For example, Berrebi and Klor (2008) and Getmansky and Zeitzoff (2014) argue that external military threat may help incumbents, but mainly if they are from the political right. From this perspective, rather than expecting support for incumbents across the political spectrum, we would expect this effect to be limited to right-wing candidates and parties. Such heightened support for the right could stem from yet another source. Throughout history, diseases appear to have gone along with heightened hostility towards outsiders (McNeill, 1976). In some cases, such hostility took extreme forms, such as the pogroms against Jews in Europe at the time of the Black Death (Perry and Schweitzer, 2002). But also today, news reports from all over the world document a rise in discriminatory behavior against

\footnotetext{
${ }^{1}$ US President Donald Trump made such remarks at press briefings (https://time.com/5806657/ donald-trump-coronavirus-war-china/, retrieved 08/04/2020) and on Twitter (https:/ / twitter.com/ realDonaldTrump/status/1239997820242923521, retrieved 08/04/2020), while Macron spoke of a war against the virus multiple times during a televised speech (https:/ /www.politico.eu/article/emmanuelmacron-on-coronavirus-were-at-war /, retrieved 08/04/2020).

${ }^{2} \mathrm{~A}$ similar prediction would follow if voters were generally conservative, i.e. biased towards the status quo. The argument here is that individuals are generally resistant to change, and this may apply even stronger in times of crises (Barber et al., 17ed; Alesina and Passarelli, 2019).
} 
Asian-looking persons in the wake of the COVID-19 pandemic. ${ }^{3}$ If voters were to express these feelings of hostility at the ballot box, we would expect an increase in vote shares for the far-right.

A radically different expectation regarding voters' emotional reactions follows from an argument by Achen and Bartels $(2012,2017)$. They posit that voters base their vote on general feelings of (dis)satisfaction, that can be influenced by events even if these are out of the control of the government. They illustrate their argument with a wave of shark attacks on the East Coast in the summer preceding the 1916 US presidential elections, which they argue let to losses in vote share for the incumbent president Woodrow Wilson. ${ }^{4}$ Drawing on county-level electoral returns, they show that the incumbent president Wilson's losses were particularly pronounced in counties most directly affected by the shark attacks that killed several swimmers and led to an economic downturn in the affected areas-popular holiday destinations-as many holiday-makers canceled their bookings. An analogous effect is described by Healy et al. (2010), who show that wins by the local college football or basketball team, positive external events, immediately preceding an election are associated with an increase in the incumbent's vote share of about 1-2 percentage points. ${ }^{5}$ Healy, Malhotra, and Mo (2010, 12804) point to psychological research showing that "people often transfer emotions in one domain toward evaluation and judgment in a completely separate domain", and that these effects "are often heightened in complex and uncertain situations." The emerging COVID-9 pandemic certainly is such a situation. We would, therefore, expect incumbent vote shares to be negatively affected in areas more severely affected by the spread of the virus. Hence, the emotion-driven perspective provides us with a range of partially conflicting predictions, ranging from increased vote shares for all incumbents, over particularized support for the political right, to a negative effect on incumbent vote shares.

\footnotetext{
${ }^{3}$ The Wikipedia article "List of incidents of xenophobia and racism related to the 2019-20 coronavirus pandemic" (https://en.wikipedia.org/wiki/List_of_incidents_of_xenophobia_and_racism_related_to_ the_2019-20_coronavirus_pandemic, retrieved 08/04/2020) compiles incidents worldwide as well as media reports documenting these incidents.

${ }^{4}$ However, their empirical claim regarding shark attacks is disputed by Fowler and Hall (2018), who find no such an effect in a larger dataset of electoral returns and shark attacks.

${ }^{5}$ But this empirical claim is also refuted by Fowler and Montagnes (2015).
} 
A second perspective sees voting during a pandemic simply as an opportunity for retrospective voting, whereby voters evaluated an incumbent's past performance in government (Key, 1966; Fiorina, 1981). Studies of retrospective voting demonstrate a link between external contexts, such as macroeconomic conditions, assuming voters to judge their personal (or, in some variants, the nation's) welfare and punishing incumbents if it decreases. They provide the empirical underpinnings to theoretical approaches to democratic accountability whereby citizens use elections to replace incompetent incumbents with more competent leaders (e.g. Besley, 2006; Fearon, 1999) and to incentivize politicians to govern effectively and honestly (e.g. Ferejohn, 1986). In this literature, natural disasters are seen as crucial test cases (Bovan et al., 2018; Gasper and Reeves, 2011; Cole et al., 2012; Bodet et al., 2016; Healy and Malhotra, 2009; Arceneaux and Stein, 2006).

Specifically, Ashworth et al. (2018) suggest that disasters provide an opportunity for voters to learn about government competence. Just as the state unemployment rate influences citizens' national retrospective economic evaluations (Ansolabehere et al., 2014), citizens may make inferences from the local affectedness of their communities to the seriousness of the pandemic. Finding a link between unexpected events and electoral outcomes is then not per se a sign of voter irrationality, as the argument by Achen and Bartels would suggest. Instead, the voters' reaction will depend on how they evaluate the government's response to the crisis. Competent responses should be rewarded, and poor performances punished. Indeed, Bechtel and Hainmueller (2011) show that voter gratitude (in terms of higher vote shares) for relief measures in response to widespread flooding in Germany could be detected years after the disaster had passed. ${ }^{6}$ Depending on how the response to the disease outbreak is evaluated, we should expect places hardest hit by the pandemic (where voters have most information on the government's response) to either punish or reward the incumbent on the ballot box. What distinguishes this perspective from the first one is that it is strongly focused on the actions of the executive or incumbent (party). Evaluative considerations, there-

\footnotetext{
${ }^{6}$ This evaluation mechanism can also be understood as a form of issue ownership voting (Petrocik, 1996): voters for whom the issue is most salient and who trust the government to handle the crisis will be most likely to vote for the incumbent. For instance, Karol and Miguel (2007) show that the number of Iraq war casualties per state was negatively correlated with the incumbent's vote share in the 2004 US presidential elections.
} 
fore, should not affect the vote shares of other parties and opposition candidates-other than by having them loose or gain votes in response to what happens to the incumbent.

As a final perspective, we explore the possibility that voters decide based on forwardlooking, strategic considerations. This perspective has been criticized in the past for promoting an unrealistically sophisticated picture of the electorate (Campbell et al., 1960; Converse, 1964). However, we argue that forward-looking motivations might be particularly pertinent in times of relatively slow-moving natural disasters and other calamities (such as wars). In the case of the COVID-19 pandemic, at the time the elections were held, case numbers and fatalities were on the rise, and the peak of the disease well out of view. We argue that in a situation like this, voters' minds should be particularly focused on the future, and they should have a strong interest in leadership that can safely steer them through the crisis. In particular, they might use the elections to align their local incumbents with the government in power at a higher level to secure more effective disaster reponse and relief for their community.

Our argument builds, on the one hand, on the US politics literature, where it has been observed that presidential coattails benefit candidates for Senate and House that belong to the winning presidential candidate's party (Campbell, 1991; Ferejohn and Calvert, 1984b; Calvert and Ferejohn, 1983). Here, a popular presidential candidate who is able to motivate voters to cast a straight-ticketoften start off their term with a majority in Congress, which they, however, loose in mid-term elections. Such coattails have been shown to apply in concomitant local mayoral and council elections, as well (Rudolph and Leininger, 2020). On the other hand, the tendency for the president's party or national governments in other cases to lose votes in mid-term (regional) elections are considered a sign of voters seeking to balance and moderate national politics in federal states (Erikson and Filippov, 2001; Alesina and Rosenthal, 1989). Importantly, for the German case, which we study, Kern and Hainmueller (2006) have shown that parties governing at the national level only loose in regional mid-term elections if they control both chambers of the national legislature providing evidence that voters use these elections to balance the power of the federal government. In normal times, electoral balancing would imply losses for the party or parties governing at a higher level of government. However, we deem it likely that voters faced with an impending crisis 
will favor a government that is able to act decisively. From this perspective, we expect voters to opt for the party or the candidate of the party that wields power at higher levels of government, too.

\section{The COVID-19 outbreak and the local elections in Bavaria}

We analyze the electoral effects of the global COVID-19 pandemic on local elections in the southern German state of Bavaria. Out of the sixteen German states, Bavaria is the largest in terms of area, second-most populous, and third-wealthiest in terms of GDP per capita. Municipalities are Germany's lowest tier of government. They are organized in counties, which provide administrative functions for groups of smaller municipalities. In larger cities, the municipality- and county-level fall together, so there is only one tier of government. ${ }^{7}$ Municipalities and counties are of substantial political and economic importance as they account for about a quarter of all total government spending. ${ }^{8}$ Municipalities are responsible for culture, sports, elementary schools, local public transport, social welfare and local infrastructure management, among others. Counties organize regional infrastructures such as hospitals and emergency services.

Local elections are held every six years, with the last major round of elections having been held in March 2014. The local elections we are analyzing took place on 15 March 2020. Around ten million voters were called to the polls to elect local councils and executives. In larger cities, where municipality- and county-level fall together, voters elected a municipal council and a mayor. In smaller municipalities, voters elected the council and mayor for their municipality as well as the council and head of the council administration of the county that their municipality was a member of. Hence, in large cities, citizens received two ballot papers, whereas citizens in smaller municipalities received four ballot papers. Our analyses are based on the electoral returns of the municipal council and mayoral elections, as well as the elections for the county council and head of the county administration.

\footnotetext{
${ }^{7}$ In 2017, the number of municipalities per county in Bavaria ranged from 11 to 58 . There were 11 cities.

${ }^{8}$ http:/ / www.bpb.de/nachschlagen/zahlen-und-fakten/soziale-situation-in-deutschland/61867/ oeffentliche-finanzen, retrieved on 16/03/2017
} 
The election date had been set on 12 February 2019-a good year before the outbreak. ${ }^{9}$ Individuals had to register their candidature by 23 January 2020, five days before the very first cases in Bavaria/Germany became known. ${ }^{10}$ This case was detected in the Bavarian state capital of Munich on 28 January 2019 in an employee working closely with a Chinese firm. The contact persons of this putative 'patient zero' were quickly identified, and the initial spread of the disease stopped. The lull did not last long, however. The virus re-appeared in Bavaria in early March, this time imported from Austria, Italy, and regions in Germany that saw early major outbreaks, such as the county of Heinsberg in the western state of North Rhine-Westfalia. ${ }^{11}$ Munich again was affected early on. However, the virus also sprung up in northern and eastern counties, including in the rural counties of Cham and Ostallgäu. In the case of Cham in eastern Bavaria, the first case was detected in a young woman who had returned from a skiing holiday in Austria's South Tirole region by coach. ${ }^{12}$ In the days that followed, several others who had been on the same coach were tested positively for the virus.

Despite the onset of the pandemic, there is little indication that the spread of the virus dominated the elections. Rather than voters being scared away from the ballot box, turnout was up in comparison to the previous election: 58.5 percent as compared to 55 percent in 2014. Being one of only three state-wide elections in Germany in 2020, the local elections were met with relatively high interest by voters. In an opinion poll held right before the elections, 79 percent of respondents indicated that they were 'strongly interested' in the elections. ${ }^{13}$ Importantly, at the time of the election the pandemic did not yet significantly affect the wider society or the economy. Drastic state-wide measures to contain the virus were put in place only after the election. Specifically, before the election, school closures were only applied in cases where there had been a

\footnotetext{
${ }^{9}$ https: / /www.stmi.bayern.de/med/aktuell/archiv/2019/191112wahl/, retrieved on 01/04/2020

${ }^{10} \mathrm{This}$ also means that candidates could therefore not have registered or withdrawn their candidacy in response to the COVID-19 outbreak, see https://www.br.de/nachrichten/bayern/kommunalwahlbayern-wie-wird-man-kandidat,RWYnKmG, retrieved on 01/04/2020

${ }^{11}$ https://www.br.de/nachrichten/bayern/weitere-corona-faelle-in-bayern-allgaeuer-firmaschliesst-vorerst,RrzIckS, retrieved on 01/04/2020

${ }^{12}$ https: / / www.br.de/nachrichten/bayern/erster-corona-fall-im-landkreis-cham,RsWdphv, retrieved on $01 / 04 / 2020$

${ }^{13}$ https: / / www.br.de/nachrichten/bayern/br-bayerntrend-grosses-interesse-an-denkommunalwahlen,Rt7Furj, retrieved on 16/03/2017
} 
verified case of COVID-19 among the student or teacher body. In essence, the Bavarian case credibly provides us with 'excludability' in causal parlance.

In our analyses, we focus on the electoral fortune of the CSU, Bavaria's dominant political party. The 'sister-party' of Angela Merkel's Christian Democratic Union (CDU) has led every state government since its founding in 1945 and governs in all but one of Bavaria's 96 counties. However, its dominance has come under pressure in recent years by challengers from both the political left and the political right. The increasing salience of environmental issues, especially climate change, is providing a boost to the green party, which, as a result, had become a serious contestant for local governing positions. On the political right, Germany's new right-wing populist party, the AfD, has been on the rise. In particular, the 'refugee crisis' of 2015 had provided a boost to the anti-immigrant party and allowed it to compete with the CSU on the issue of immigration and security.

The CSU is also the dominant party in Bavaria's municipal politics, holding the mayoralty in more than a third of Bavaria's 2056 municipalities. The Social-democratic Party of Germany (SPD) comes in a distant second place with just over 200 mayors among its ranks, particularly in larger cities. Many municipalities, in particular smaller ones, are headed by independent mayors not affiliated with any of the large parties represented in the national parliament. They have been nominated by local voter groups, ${ }^{14}$ many of which are associated with the Free Voters (FW). ${ }^{15}$ The FW are an umbrella organization for local Free Voter groupings and also compete in state elections. As such, the FW are an important player in local politics as well as at the state level, because they form a coalition with the CSU to form the state government. While their ideological outlook is generally socially conservative, they pursue a pragmatic approach in politics cooperating within varying coalitions in the municipalities in which they are represented (Fuchs, 2010). In the 2020 county council elections that we study, the CSU garnered $34.5 \%$ of the vote state-wide, while the SPD and FW obtained vote shares of only $13.47 \%$ and $11.9 \%$ respectively. ${ }^{16}$

\footnotetext{
${ }^{14}$ In Bavaria, individuals cannot self-proclaim their candidacy but must be nominated by a party or local voters' association.

${ }^{15}$ Short for "Freie Wähler" (Free Voters).

${ }^{16}$ https://www.kommunalwahl2020.bayern.de/ergebnis_gremien_wahlvorschlag_aktuell_1_990. html, retrieved 08/04/2020
} 
Our focus on the CSU, therefore, is warranted by its status in Bavarian politics and the theoretical considerations introduced above, most of which focus on the incumbent party. Based on the three theoretical perspectives, how should we expect the CSU to fare? First, regarding the emotion-driven perspective, the rally-'round-the-flag argument predicts general support for incumbents. We might, therefore, expect the CSU to do well in places hit by the COVID-19 pandemic where it was already in power, but should expect incumbents of other parties do equally well in such places. Should voters rally around the state government, we may expect the CSU, and possibly also its junior coalition partner FW, to do better in places more strongly affected by COVID-19 even when it does not hold the mayoralty. If instead, voters are motivated by outgroup hostility, they should opt for the populist radical-right AfD at higher rates where the disease is spreading. ${ }^{17}$ And if voters mainly act out their negative feelings, this should hurt incumbents across the board.

Second, from the perspective of evaluative or retrospective voting, how the CSU fared in areas affected by the crisis depends mainly on whether voters believe the government's handling of the crisis to be satisfactory. Again, in principle, that should apply to incumbents of all parties. Finally, if voters were interested to strategically align their local governments with higher levels, this should clearly benefit the CSU, which not only leads the state government but also holds the position of the interior minister in the national government.

Our analyses are complicated by the fact that politics takes place at several levels. Voters might focus purely on the local level or might use their vote to react or send a signal to higher levels of government (Dinkel, 1977; Hopkins, 2018; Kern and Hainmueller, 2006). This is certainly applicable in the case of Germany's differentiated system of federalism, where all levels of government carry responsibilities for disaster relief and preparedness. We have to keep this complication in mind in the analyses that follow.

\footnotetext{
${ }^{17}$ While the CSU is generally seen as also leaning towards the political right (more so than the CSU), its leader Markus Söder has clearly positioned its party as anti-xenophobic and ruled out any cooperation with AfD. Voters acting on the basis of hostility should, therefore, be drawn to give their vote to the AfD.
} 


\section{Empirical strategy}

\section{Data sources}

Data on COVID-19 cases at the county level come from the website of the Bavarian Ministry for Health and Consumer Protection. ${ }^{18}$ We use cases published online before 6 pm on 15 March 2020, the closing of polls on election day. The ministry started systematically reporting cases from 9 March on. Figure 1 depicts the distribution of known cases on the election day and evolution over time for the days between 9 and 15 March, the day of the municipal elections. As can be glanced from the map, on election day, the disease had affected all parts of Bavaria, but with substantial variation in local prevalence. Counties with high numbers of COVID-19 cases can be found next to counties where no or very few cases were registered. What is more, there is no clear rural-urban pattern. While the capital Munich naturally saw many cases due to its high population numbers, other urban areas like Regensburg or Augsburg show only a few cases. In contrast, some rural counties such as the already-mentioned county of Cham (northeast of Regensburg) or Rottal-Inn (west of Passau) saw relatively high case numbers. Moreover, while the area surrounding Munich appears to show a concentration of cases, some close-by counties had not experienced any cases on the day of the election.

In order to test for the existence of a spatial pattern in the distribution of COVID-19 cases more formally, we calculated Moran's I and Geary's C, measures for global and local spatial autocorrelation. We calculated The measures for the election day as well as for each of the six days leading up to the election (i.e., 9-15 March 2020). For none of the days preceding the election do the measures reach conventional levels of statistical significance (all $\mathrm{p}>0.1$ ). This finding is all the more remarkable as the measures are sometimes criticized for being overly sensitive (Anselin and Rey, 1991). Only for the election day itself does the p-value for Moran's I become borderline statistically

\footnotetext{
${ }^{18}$ https://www.lgl.bayern.de/gesundheit/infektionsschutz/infektionskrankheiten_a_z/ coronavirus/karte_coronavirus/index.htm
} 


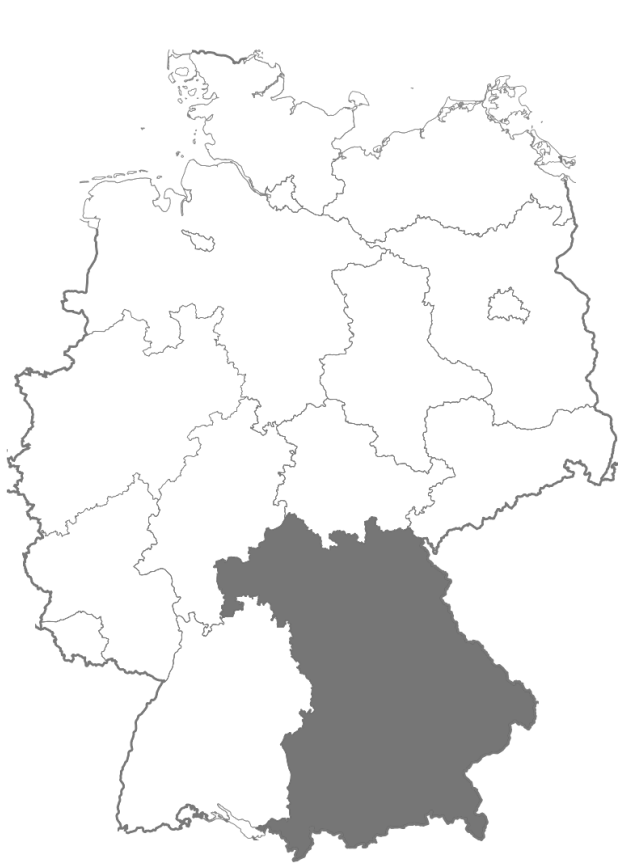

(a) Location of Bavaria in Germany

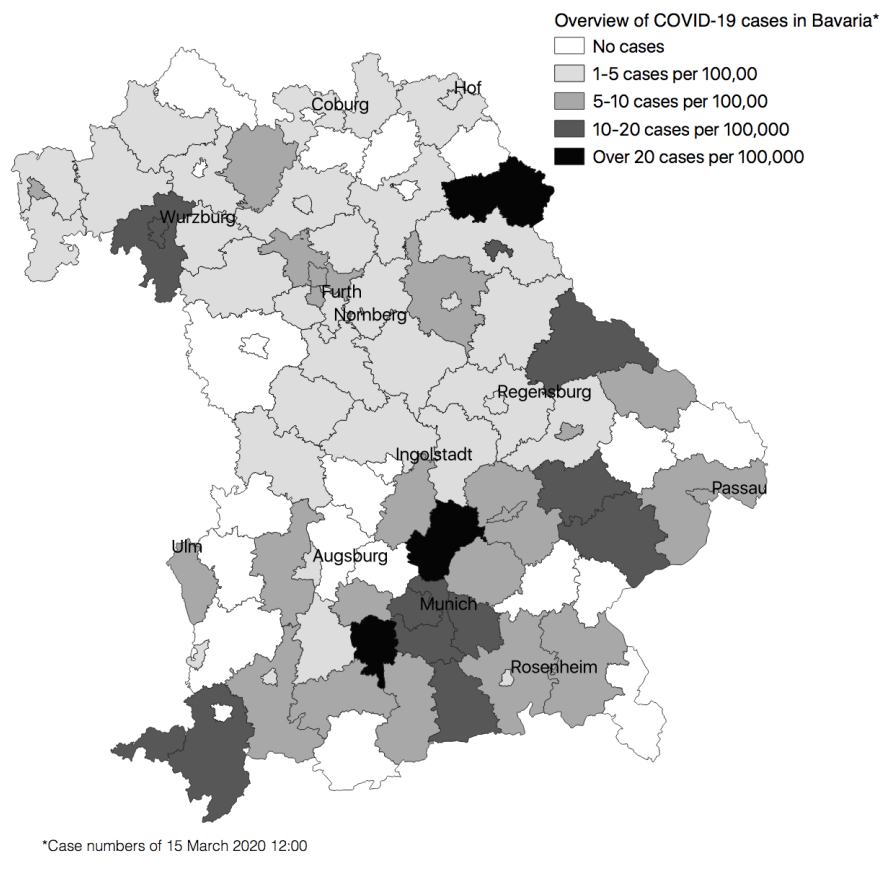

(b) Distribution of COVID-19 cases, 15 March
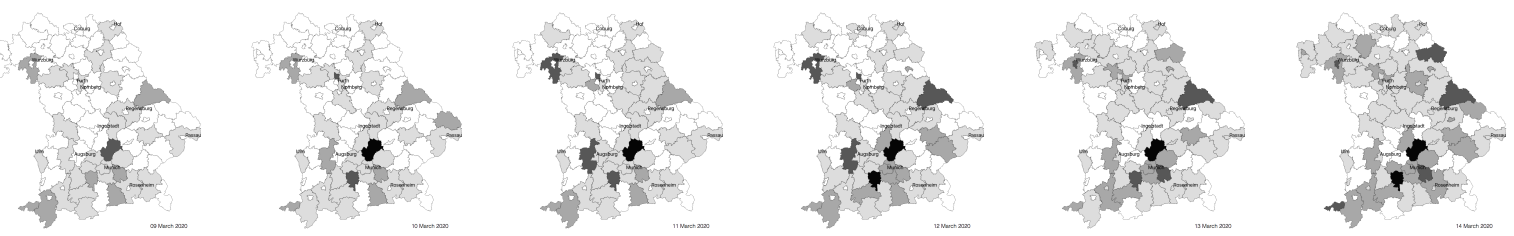

(c) Evolution of COVID-19 prevalence in days leading up to election (9-14 March 2020)

Note: The figure shows the location of Bavaria in Germany (Figure 1a), the distribution of known COVID19 cases in the 96 Bavarian counties as of 12am on 15 March 2020, the day of the local elections (Figure $1 b$ ), and the evolution of cases during the six days leading up to the election 9-14 March 2020 (Figure 1c). Maps compiled by the authors based on data from the Bavarian Ministry for Health and Consumer Protection.

significant $(\mathrm{p}=0.099) .{ }^{19}$ Relatedly, in Table A3 we show pairwise correlations between the prevalence of COVID-19 cases, and our control variables. Only one out of ten correlations is statistically significant, testifying to the lack of a pattern in the spread of the disease at the time of the local elections.

Since the official COVID-19 data are only published at the county level, we needed to find an alternative measure for affectedness by the disease. For this we rely on a list of school closures published on 13 March 2020, shortly before the elections. At this point,

\footnotetext{
${ }^{19}$ In line with this, and as further explained below, spatial autoregressive versions of our regression models fail to detect spatial autocorrelation.
} 
school closures where still decided on a per-case basis by individual municipalities whenever a student, parent, or someone from the wider environment surrounding the school was suspected of having infected the disease. Some schools closed fully, others only asked individual classes to stay home. Indeed, many schools sought to open in the week of 20 March. This never happened. From the day after the elections, all schools in Bavaria had to close. ${ }^{20}$ In our models (which we introduce next), we use an indicator that takes the value of one for municipalities where one or more schools had to close, and zero for municipalities without school closures before the day of the election.

For the electoral data, we rely on publications by the Bavarian returning officer as well as a local newspaper. Here, we look at two different types of elections at two different levels of government; i.e. four elections in total. The elections for the municipal council (Gemeinderat, which is the municipal legislative assembly) and the county council (Kreistag, the legislative assembly at the county level) are held according to proportional representation. The elections for mayors (Bürgermeister) and heads of the country administration (Landrat) follow a majoritarian system.

From the returns to these elections we constructed three separate datasets. The first dataset contains the results of the elections to the councils of the counties and larger cities only-96 elections in total. We use vote shares from the first (and only) round of these elections. The second dataset contains the results of executive elections in the counties, larger cities and municipalities with more than 10,000 inhabitants. ${ }^{21}$ These elections are held following a two-stage procedure. In the first round, all parties and local voters associations can, and many do, field a candidate. If no candidate reaches an absolute majority in the first round, a second round is held two weeks after. The two candidates that received the highest vote share in the first round enter this runoff election. Since we are particularly interested in the CSU, we use the party's vote share in the first round, wherever it fielded a candidate in both the 2014 and 2020 elections.

\footnotetext{
${ }^{20}$ While school closures might not capture all of the cases, we still deem this a relatively good measure since the number of people that are involved with schools in one way or another is large, and since school closures would be widely communicated. Importantly, unlike information derived from press reports (which often do not cite precise municipality names), looking at school closures gives us systematic measure.

${ }^{21}$ The results for council elections in Bavaria's 2031 other municipalities are not compiled by the state returning officer or in fact any other state institution. We therefore rely on data collected by a regional newspaper, as explained below.
} 
This was the case in 85 of the 88 counties and larger cities and in 162 of the 189 larger municipalities in which elections took place. ${ }^{22}$ Our second dataset therefore comprises 247 electoral results. ${ }^{23}$

In our third dataset, we supplement these data with the results of mayoral elections in small municipalities with under 10,000 inhabitants. These were collected and assembled by a regional newspaper and generously shared with us. ${ }^{24}$ In total, the data comprise results for 1,285 mayoral elections contested by the CSU. While they are less complete than those published by the returning officer-we lack results for the prior electionthey allow us to look into the dynamics within counties.

\section{Estimation strategy}

Our general strategy is to compare electoral outcomes in counties that were not or only mildly affected by the pandemic with those in more heavily affected counties. In order for the analysis to have a causal interpretation, the pandemic should not have systematically affected counties where the decline in support for the CSU would have been lower in the absence of the pandemic due to some confounding factors. As already mentioned, the irregular pattern in the spread of the disease reduces this threat. Beyond relying on this pattern, we pursue several strategies to account for possible confounders.

\footnotetext{
${ }^{22}$ Bavaria has 71 counties in total, only seven of which (Coburg, Dillingen a.d. Donau, Kronach, Lichtenfels, Roth, Neuburg-Schrobenhausen, and Regen) hold off-cycle executive elections dues to idiosyncratic reasons such as resignations or deaths of incumbents, and 25 larger cities at the rank of a county. Of the latter only one (Memmingen) holds off-cycle elections for said reasons.

${ }^{23}$ This data set combines results for elections to the head of the county administration, the mayor in larger cities, where municipality- and county-level fall together, and mayors of larger municipalities, but which are not large cities. The latter are nested within aforementioned counties. We employ bootstrapping with drawing from county units to take into account this clustering in the data.

${ }^{24}$ The data was collected for the newspaper Merkur by the Ippen-Digital-Zentralredaktion, details on the-suprisingly cumbersome-process of collecting these data can be found on https:/ / www.merkur. de/politik/kommunalwahl-bayern-2020-wahlergebnisse-datenjournalismus-zr-13593651.html. Note that the newspaper collected these data directly from municipalities because the state returning officer does not compile electoral results for local elections in municipalities with less than 10,000 inhabitants. Because the newspaper Merkur only began to collect these data n 2020 we lack the data on local elections in small municipalities in 2014.
} 
First, we are comparing changes in vote shares for the same county between the current and the previous election. This means that time-invariant differences between counties should not influence our estimates. However, the support for the incumbent party could also have been influenced by dynamic developments over time, such as diverging trends in terms of economic and demographic developments. In particular, population growth, changes in the share of the foreign population, and economic growth or decline come to mind. We control for these factors in a regression model of the form

$$
\Delta \operatorname{CSU}_{c, 2020-14}=\ln (\operatorname{COVID-19/100k})_{c, 2020}+X_{c_{t}}+\Delta X_{c, t-t-1}+\epsilon_{c} .
$$

The dependent variable in this model is the change in vote shares for the CSU between the current and the previous election in a given county $c$. Our main independent variable is the logged number of COVID-19 cases per 100,000 inhabitants in a county. We control for variables $X$ measured shortly before the outbreak of the epidemic (subscripted with $t$ ), and the trend in these variables between the two elections, the term $\Delta X_{c, t-t-1}$. We use $t$ and $t-1$ because not all data is available for the same years. Most variables are measured between 2012 and 2017, some between 2013 and 2018, and yet others between 2013 and 2019.

The time between the two elections was marked by stable economic growth and a strong labor market. Since counties may have nevertheless been affected unequally, we include indicators for population density, the total number of employees of all companies in a county, the unemployment rate, and the change in those variables. Further, the year 2015 saw the arrival of 1.5 million refugees in Germany. To account for the potential effects of the hosting of refugees, we include the level and change in the share of the foreign population. Finally, our model controls for the level and change in the population aged 60 years or more. This group is particularly important because it traditionally supports the CSU at higher rates, and is also at much higher risk by COVID-19.

Second, we estimate a difference-in-differences model of the form

$$
\operatorname{CSU}_{c, t}=\gamma_{c}+\ln (\operatorname{COVID}-19 / 100 k)_{c, t}+X_{c t}+\epsilon_{c, t}
$$


Here, the $t$ subscript denotes the years 2014 and 2020, and $\gamma_{c}$ are county-fixed effects. That is, with this model, we look at within-county change in the vote shares for the CSU between 2014 and 2020. This specification takes into account all time-invariant factors that distinguish counties from each other, such as their population size, remoteness, etc. In order to account for dynamic developments between the two elections, we also control for the change in our control variables. In all our models, we bootstrap standard errors, resampling at the county level. This is specifically recommended for the DiD specification to take into account that observations are not independent of each other (Bertrand, Duflo, and Mullainathan, 2004), and also makes our models more robust against the effect of outliers.

As we are lacking data on previous elections for the mayoral elections in the municipalities, the model here is a simple cross-section model in the form

$$
\operatorname{CSU}_{m, c}=\gamma_{c}+\text { closure }_{m}+X_{m}+\text { inc.party } m+\epsilon_{m, c}
$$

where we use as dependent variable either the vote share of the CSU candidate, or a dummy coding whether a CSU incumbent was successful in holding or gaining office. As before, we control for potential confounders $X$, this time measured at the municipality level. The fact that all our data is at the municipality levels means that we can again use county fixed effects $\left(\gamma_{c}\right)$. That is, our estimates rely on variation between affected and unaffected municipalities while holding county-level attributes constant. In order to improve the precision of our estimates, we also include a dummy for the incumbent party in our models. ${ }^{25}$

\section{Results}

We start by graphically depicting the relationship between the change in vote shares for the CSU against the number of COVID-19 cases in a given county (Figure 2). We see that the CSU lost vote shares in all but three counties. We also observe an overall positive relationship between the electoral support for the CSU and the number of

\footnotetext{
${ }^{25}$ Excluding these additional controls only minimally affects the substantive estimates.
} 
COVID-19 cases. While this relationship is less clear when using raw numbers due to two outliers, the relationship closely approximates linearity when using logged case numbers. In counties with a higher prevalence of the disease, the losses of the CSU were more limited. The spread of the disease appears to have helped the incumbent party.

Figure 2: Change in CSU vote share relative to COVID-19 cases
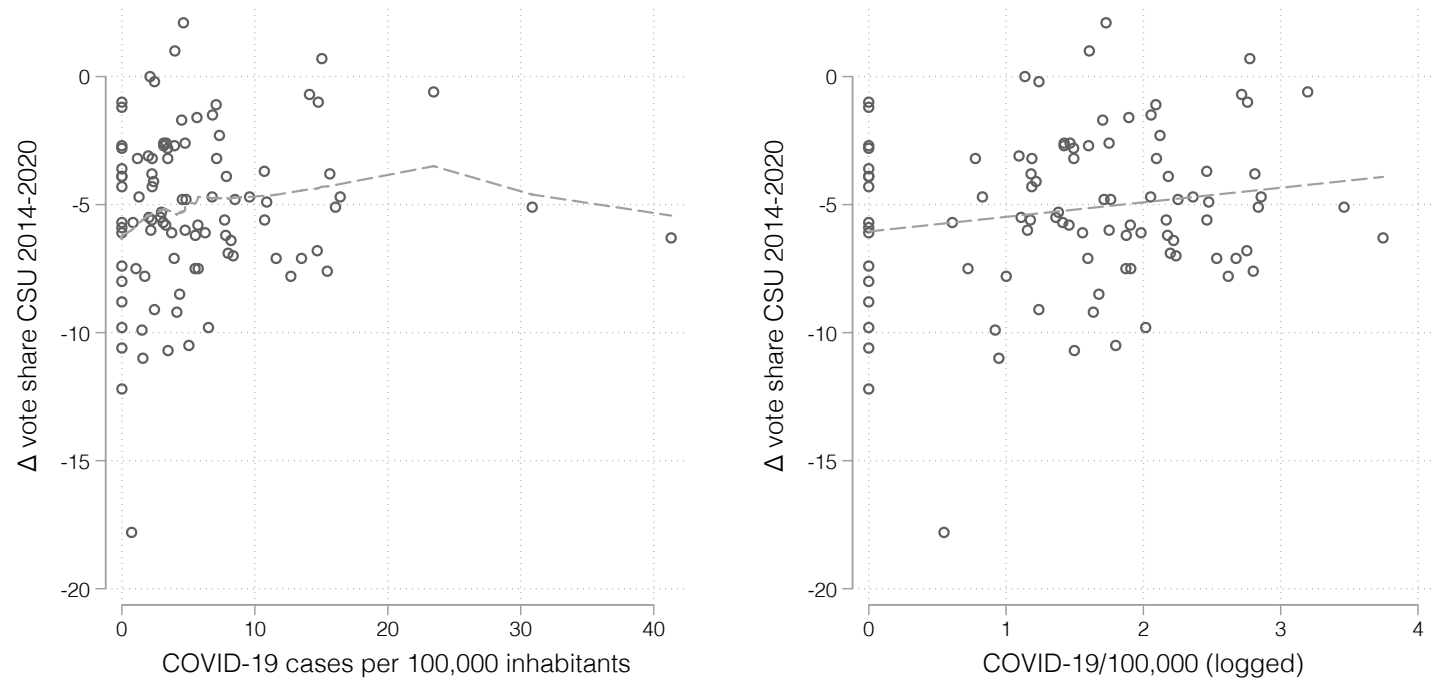

Note: The figure plots the number of COVID-19 cases against the change in vote share for the CSU between the county elections 2014 and 2020 using raw case numbers per 100,000 inhabitants (left), and the natural logarithm (right). The dashed lines are from a locally-weighted regression smoother (left) and a linear regression (right), respectively.

Next, we test whether this initial impression holds up to econometric testing. Table 1 displays the results for regression models of the change in CSU vote share on the logged number of COVID-19 cases following the specifications introduced above. Column (1) shows the specification with the CSU change score as the dependent variable and using data from the county elections. In this model, a one-unit increase in logged case numbers corresponds to a 0.88 percentage points higher vote share for the CSU. Expressed in total numbers, this means that a county with three cases per 100,000 inhabitants has a roughly one percentage points higher CSU vote share than one with none, a county with ten cases per 100,000 inhabitants a two percentage points higher vote share, and one with 30 cases per 100,000 inhabitants a three percentage points higher vote share. Column (2) repeats the analysis with the difference-in-differences 
specification (Equation 2). Here, the estimated effect is slightly lower (0.71) but remains statistically significant. ${ }^{26}$

Table 1: Regression of change in CSU vote share on COVID-19 prevalence

\begin{tabular}{|c|c|c|c|c|c|c|}
\hline \multirow{2}{*}{$\begin{array}{l}\text { Type } \\
\text { Model }\end{array}$} & \multicolumn{2}{|c|}{ Counties } & \multicolumn{2}{|c|}{ Mayoralities } & \multicolumn{2}{|c|}{$\begin{array}{c}\text { Small municipalities } \\
\text { Cross section }\end{array}$} \\
\hline & (1) & (2) & (3) & (4) & (5) & (6) \\
\hline COVID-19/100,000 (logged) & $\begin{array}{l}0.88^{*} \\
(0.34)\end{array}$ & & $\begin{array}{l}3.42^{*} \\
(1.38)\end{array}$ & & & \\
\hline COVID-19 × Year 2020 & & $\begin{array}{l}0.71^{*} \\
(0.34)\end{array}$ & & $\begin{array}{l}2.88^{*} \\
(1.26)\end{array}$ & & \\
\hline School closure due to COVID-19 case & & & & & $\begin{array}{l}6.12^{*} \\
(2.94)\end{array}$ & $\begin{array}{l}0.17^{*} \\
(0.07)\end{array}$ \\
\hline Population density 2018 (10k/km2) & $\begin{array}{c}0.24 \\
(2.10)\end{array}$ & & $\begin{array}{l}-5.35 \\
(8.33)\end{array}$ & & $\begin{array}{l}-1.50 \\
(4.29)\end{array}$ & $\begin{array}{l}-0.02 \\
(0.10)\end{array}$ \\
\hline$\Delta$ Population density $2013-18(10 / \mathrm{km} 2)$ & $\begin{array}{l}-0.20 \\
(0.30)\end{array}$ & $\begin{array}{l}-0.07 \\
(0.13)\end{array}$ & $\begin{array}{l}-0.74 \\
(1.28)\end{array}$ & $\begin{array}{l}-0.80 \\
(0.49)\end{array}$ & $\begin{array}{c}0.24 \\
(0.66)\end{array}$ & $\begin{array}{l}-0.00 \\
(0.02)\end{array}$ \\
\hline Share foreign population 2017 (\%) & $\begin{array}{l}-0.38^{*} \\
(0.16)\end{array}$ & & $\begin{array}{l}-0.66 \\
(0.76)\end{array}$ & & $\begin{array}{c}0.05 \\
(0.26)\end{array}$ & $\begin{array}{c}0.00 \\
(0.01)\end{array}$ \\
\hline$\Delta$ Share foreign pop $2012-17(\%)$ & $\begin{array}{c}0.57 \\
(0.35)\end{array}$ & $\begin{array}{c}0.27 \\
(0.30)\end{array}$ & $\begin{array}{c}0.96 \\
(1.94)\end{array}$ & $\begin{array}{c}0.43 \\
(1.63)\end{array}$ & $\begin{array}{l}-0.11 \\
(0.48)\end{array}$ & $\begin{array}{c}0.01 \\
(0.01)\end{array}$ \\
\hline Unemployment rate 2019 (\%) & $\begin{array}{c}0.52 \\
(0.54)\end{array}$ & & $\begin{array}{c}2.53 \\
(2.02)\end{array}$ & & $\begin{array}{c}0.11 \\
(0.18)\end{array}$ & $\begin{array}{c}0.00 \\
(0.00)\end{array}$ \\
\hline$\Delta$ Unemployment rate $2013-19(\%)$ & $\begin{array}{l}-0.16 \\
(0.09)\end{array}$ & $\begin{array}{l}-0.13 \\
(0.07)\end{array}$ & $\begin{array}{l}-1.01^{*} \\
(0.33)\end{array}$ & $\begin{array}{l}-0.74^{*} \\
(0.29)\end{array}$ & $\begin{array}{l}-0.07 \\
(0.23)\end{array}$ & $\begin{array}{l}-0.00 \\
(0.00)\end{array}$ \\
\hline Aged 60 or above $2017(\%)$ & $\begin{array}{c}0.05 \\
(0.22)\end{array}$ & & $\begin{array}{l}-0.40 \\
(0.77)\end{array}$ & & $\begin{array}{l}-0.44 \\
(0.23)\end{array}$ & $\begin{array}{l}-0.00 \\
(0.01)\end{array}$ \\
\hline$\Delta$ Aged 60 or above $2012-17(\%)$ & $\begin{array}{l}-0.23 \\
(0.69)\end{array}$ & $\begin{array}{c}0.83 \\
(0.55)\end{array}$ & $\begin{array}{l}-0.61 \\
(2.64)\end{array}$ & $\begin{array}{c}1.01 \\
(1.87)\end{array}$ & $\begin{array}{c}0.24 \\
(0.61)\end{array}$ & $\begin{array}{c}0.00 \\
(0.01)\end{array}$ \\
\hline Nr of employees 2017 (1k) & $\begin{array}{c}0.08 \\
(0.06)\end{array}$ & & $\begin{array}{c}0.35 \\
(0.19)\end{array}$ & & $\begin{array}{l}-0.05 \\
(0.46)\end{array}$ & $\begin{array}{l}-0.00 \\
(0.01)\end{array}$ \\
\hline$\Delta \mathrm{Nr}$ of employees 2012-17 (1k) & $\begin{array}{l}-0.62 \\
(0.40)\end{array}$ & $\begin{array}{l}-0.49 \\
(0.36)\end{array}$ & $\begin{array}{l}-0.45 \\
(1.21)\end{array}$ & $\begin{array}{c}0.49 \\
(0.88)\end{array}$ & $\begin{array}{c}1.62 \\
(1.71)\end{array}$ & $\begin{array}{c}0.00 \\
(0.05)\end{array}$ \\
\hline Year 2020 (const. term) & & $\begin{array}{l}-7.47^{*} \\
(1.39)\end{array}$ & & $\begin{array}{l}-10.35 \\
(5.89)\end{array}$ & & \\
\hline County FE & - & Yes & - & Yes & Yes & Yes \\
\hline Incumbent FE & - & - & - & - & Yes & Yes \\
\hline Intercept & $\begin{array}{l}-7.39 \\
(5.91)\end{array}$ & $\begin{array}{c}29.59 \\
(19.23)\end{array}$ & $\begin{array}{c}-3.48 \\
(21.79)\end{array}$ & $\begin{array}{c}57.27 \\
(65.53)\end{array}$ & $\begin{array}{l}67.38^{*} \\
(6.65)\end{array}$ & $\begin{array}{l}0.66^{*} \\
(0.15)\end{array}$ \\
\hline $\mathrm{N}$ & 96 & 192 & 247 & 494 & 1,285 & 1,018 \\
\hline $\mathrm{R} 2$ & 0.27 & 0.95 & 0.06 & 0.36 & 0.21 & 0.21 \\
\hline
\end{tabular}

Note: OLS regression of the electoral outcomes for the CSU and its candidates on COVID-19 prevalence. The dependent variables are a) the change in the vote share for the CSU in the county council elections (Columns $1 \& 2$ ) between the 2020 and the previous election (mostly held in 2014), b) the change in vote share for the CSU candidate in the elections for the post of county executive or mayor in cities and larger municipalities (Columns 3 \& 4), c) the vote share received by CSU candidates in the first round of all mayoral elections (including those held in small municipalities) in 2020 (Column 5), and an indicator taking the value of 1 if a CSU candidate won a mayoral race in the first round, and 0 if $\mathrm{s} /$ he lost (Column 6). The main independent variables are the logged number of COVID-19 per 100,000 inhabitants (Columns 1-4), and an indicator taking the value of 1 if a school in a municipality was closed and zero if not (Columns 5 \& 6). Bootstrapped standard errors in parentheses, resampling at county level, 1,000 repetitions, ${ }^{*} \mathrm{p}<0.05$.

\footnotetext{
${ }^{26}$ Figure $\mathrm{A} 1$ in the Appendix plots trends in average vote shares for the CSU and other major parties in the elections 2002, 2008, 2014, and 2020 for treatment and control counties. While the relatively less steep decline in CSU vote shares in areas affected by the COVID-19 outbreak is clearly visible, we note that pre-treatment trends for the CSU are not parallel. We therefore also present a version of the figure where we apply inverse-probability-weighting before plotting the graphs. In this version, trends of CSU shares move in parallel save for the difference in vote shares 2014-2020, where the decline again is less steep in areas strongly affected by the outbreak.
} 
Columns (3) and (4) repeat the analysis for the data on the elections of mayors and county executives. In these elections, overall vote shares and variability in vote shares are generally much higher. Vote shares for CSU candidates range from 5 to 96 percent (see Table A1 with summary statistics in the Appendix). The effect of the spread of the disease is also more pronounced: a one-point increase in the logged number of COVID-19 cases is associated with an estimated 3.42 percentage points higher vote share for the CSU candidate. That is, for three known cases per 100,000 inhabitants, the effect is roughly 4 percentage points, for 10 cases 8 percentage points, and for 30 cases 12 percentage points. Again, the difference-in-differences specification suggests a slightly smaller effect size of 2.88 , corresponding to an estimated 10 percentage points higher vote share in counties with 30 know cases-but is similarly precisely estimated. The analysis, therefore, demonstrates substantial electoral gains for the incumbent party and its candidates due to the spread of the COVID-19 pandemic.

Finally, Columns (5) and (6) allow us to test whether our findings hold at the very local level and when using an alternative specification of affectedness by the spread of the disease and comparing municipalities within the same counties. As shown, CSU candidates fared better in municipalities where schools had to close due to COVID-19 cases. On average, their votes shares are up about six percentage points compared to candidates in not-immediately affected municipalities of the same county (Column 5). This increase in vote share also translates into a higher probability of gaining or retaining office: CSU candidates in municipalities with school closures had a 17 percent increased chance to win their election (Column 6). ${ }^{27}$ The onset of the COVID19 pandemic, it appears, benefited candidates of the dominant party at all levels of government due for election.

In Section B.3 of the Appendix, we demonstrate that our results are robust to a range of specifications, including to varying the set of control variables, to applying inverse probability weighting, and to matching with increasingly punishing calipers. We present balance statistics (see Table A2) that show that except for being somewhat

\footnotetext{
${ }^{27}$ We only look at results where a decisive outcome was achieved in the first round of elections, for two reasons. First, the situation with regard to the spread of the COVID-19 disease was very dynamic, and lots of additional factors could have influenced the second round of elections, held two weeks later. Second, just after the first round of elections, all schools in Bavaria had to close, which means that we can no longer measure municipality-level affectedness by the virus with school closures.
} 
older and having somewhat higher unemployment rates, counties with a significant prevalence of COVID-19 are very similar to counties without cases. Furthermore, these differences vanish entirely when using the matched sample. We also calculate several spatial-econometric models, including a spatial-lag and spatial-error model, and a specification using Conley standard errors. None of these specifications hints at a distinct spatial pattern in the spread of the disease, increasing our confidence in the causal interpretation of our findings. In addition, we present placebo tests where we regress the results of the European elections 2019, the Bavarian state-level elections of 2018, and the German general elections of 2017 on our indicator for affectedness by the spread of COVID-19. In all cases, effects sizes are close to zero and not statistically significant, increasing our confidence that the change in CSU vote share 2014-2020 is unlikely to be driven by unobserved characteristics systematically favoring the party in areas affected by the COVID-19 outbreak.

\section{Evidence on mechanisms}

We continue our analysis by exploring which of the three theoretical perspectives we discussed can best account for our findings. We proceed by deriving additional empirical implications for each of them and then test these implications against the available evidence.

Our first contender for explaining electoral behavior in the case of a calamity like the COVID-19 outbreak was the emotional response triggered by the event. External threats have been shown to induce 'rallying 'round the flag' - a tendency of citizens to unite behind the incumbent in times of crisis. If this were the case, we should see higher electoral support for the dominant party, which is indeed what we find. We should also find a general pro-incumbent effect: voters should support the local incumbent no matter whether the incumbent belongs to the CSU or a different party. We test this idea in Table A10, where we test for an additional effect of incumbency for CSU candidates, and compare vote shares for incumbents of different parties. As can be glanced from the Table, the incumbency effect is not supported by the data. Columns (1) and (2) of Table A10 suggest that increased vote shares for the CSU and its candidates are driven by 
support for the party, not the incumbent as such: the interaction between incumbency and COVID-19 prevalence is positive, but fails to reach statistical significance. A similar pattern can be seen in Columns (3) to (8), which shows that only CSU incumbents gained in areas more strongly affected by the virus-in line with the overall gain in vote shares for the party. Incumbents of all other parties lost.

Alternatively, we hypothesized that the anxiety induced by the crisis might benefit the far right. At least for the point in time of our study, this hypothesis is emphatically rejected by our data. As can be seen in columns (7) and (8) of Table A9, the AfD clearly lost vote shares in areas more strongly affected by the spread of the virus. Similarly, since all our empirical results indicate a positive effect on voting for the incumbent party CSU, our analysis does not support the idea that voters would turn against the government after a natural disaster. The idea here was that governments would be punished for the COVID-19 outbreak because it induces negative feelings, such as fear, anxiety, or helplessness, in the electorate, which would translate into negative feelings towards the incumbent (party) and corresponding voting patterns. Our findings point in the exact opposite direction: rather than loosing out, the incumbent party CSU did better in areas with more cases of COVID-19. Despite the intuitive appeal of such arguments, our data, therefore, provide little evidence that voters decided based on their emotions.

Did voters evaluate their incumbent's performance during the crisis instead? In view of the overall beneficial effect of the spread of the disease on electoral support for the CSU, and if we believe that voters use elections to hold politicians accountable for its handling of the pandemic, our results suggest that voters must have evaluated them positively. Evidence for this conjecture is not easily derived from our data, so we bring in additional information. For one, the elections were held early during the pandemicseveral counties had not seen any COVID-19 cases yet. So we may wonder whether voters had had enough time to evaluate their candidates/incumbents performance. In fact, there is little indication that the spread of the virus dominated the elections. Rather than voters being scared away from the ballot box, turnout was up in comparison to the previous election: 58.5 percent as compared to 55 percent in 2014. 
Next, we test if preparedness and the early response to the crisis made a difference to the electoral fortunes of the candidates. The literature on natural disasters suggests that voters do take into account disaster relief measures when they vote in the aftermath of a disaster (Bechtel and Hainmueller, 2011; Gasper and Reeves, 2011; Cole et al., 2012; Healy and Malhotra, 2009) As an additional test, we, therefore, run models in which we interact our measure for COVID-19 prevalence with indicators for preparedness and disaster response. Our preparedness measure is the level and change in the number of hospital beds in a county in the years preceding the election. ${ }^{28}$ During the outbreak, voters might give a particularly close look at the state of the hospitals, and might punish the politically responsible politician or party if learning that capacities were low or even reduced under their rule. As for the relief measures, some counties (but not others) early on during the crisis set up test and information centers regarding the outbreak. It is possible that voters rewarded this early response by supporting their county executives and mayors at the ballot box.

We hand-collected information on the existence and location of the centers, and interact the logged number of COVID-19 cases with a dummy for their presence. ${ }^{29}$ Columns (1) and (2) in Table A11 show the interactions for the council elections, and columns (3) to (6) for the elections of city mayors and county executives of the CSU and other parties. As can be seen, both types of interactions change signs across the different models and are highly imprecisely estimated, while the indicator for COVID-19 prevalence stays significant in all models involving the CSU. In other words, retrospective evaluations of candidate performance in terms of preparedness or early response appear to play little role in explaining the effect of disease prevalence on support for the CSU.

Polling data can also help us to check if the incumbent party was evaluated positivelyand the timing of this effect. Unfortunately, there exist no polling data for individual counties. Instead, we rely on polls evaluating the leadership at the state level. Figure A3 in the Appendix shows approval rates for the Bavarian state prime minister (Ministerpräsident) from polls conducted 10 days before, 3 days after, and 10 days after ten

\footnotetext{
${ }^{28}$ We use figures for 2012 to 2017, the latest available. We also control for the overall number of hospital beds in 2012.

${ }^{29}$ The first test center was set up on 2 March 2020 in the county of Cham. Until 15 March 2020 (the day of the elections), 15 counties had established test or information centers.
} 
days the elections. We see that approval ratings between the last two polls are on a steep ascent as the prime minister is widely seen to handle the crisis well. However, crucially, this trend was not yet visible in the period before the election: the approval ratings here are largely stable. This suggests that during the first round of the elections, it was still too early for evaluative considerations of whether the government should be held accountable for this crises to decisively influence the elections. ${ }^{30}$ This additional piece of evidence also speaks against any rally-'round-the-flag effect direct at the state leadership.

As a final mechanism, we further evaluate the forward-looking perspective. The idea here is that voters look ahead to align themselves with the party that they deem most capable of helping them through the crisis. In particular, this means aligning their local party and candidate with the party in power at a higher level of governmentputatively in the belief that this will give them preferential access to potential support measures. This mechanism predicts higher vote shares for the CSU, and its candidates, which is indeed is what we find. What is more, for the mayoral races, it does not matter whether a candidate is an incumbent or not: all that matters is that she or he belongs to the dominant party, the CSU. The fact that CSU incumbents do not seem to profit over and above the general positive effect for the CSU therefore also is in line with this mechanism.

The existence of a multitude of parties at the very local level allows for another test. Unlike at the county and state level, where the CSU clearly dominates, municipalities often have mayors from local voter groups. While some of these are organized fully independently, others have aligned themselves with the FW. Recall that the FW is a regionalist party with a number of strongholds throughout Bavaria, where it controls the county administration and mayoralties. Importantly, the FW is in a coalition government with the CSU at the state level, where it holds 13 percent of the seats in the state legislature and five cabinet appointments.

If voters are acting strategically, they could also opt for an FW candidate, especially in municipalities where no CSU candidate contested the elections. The FW contested a

\footnotetext{
${ }^{30}$ The polling data also implies that no 'rally round the flag effect had set in with regard to the state leadership at this point in time.
} 
total of 820 mayoral races, 80 in municipalities where it fielded a joint candidate with the CSU, 232 in municipalities where the CSU did not run a candidate, and 509 in municipalities where FW candidates competed directly with CSU candidates. Table A12 shows results for separately for municipalities where the FW competed with the CSU, and where it ran without the competition of its coalition partner at the state level.

Columns (1) and (2) present the results for vote shares. ${ }^{31}$ Here we see that FW results where negatively effected by COVID-19-related school closures in places where it faced competition by the CSU, and positively where it did not. None of the estimates reach conventional levels of statistical significance, however. Columns (3) and (4) repeat this exercise for the probability that an FW candidate won. The results mirror those for the vote shares. Where the FW had to compete with the CSU, the chances of winning a mayoralty of a COVID-19-affected municipality decreased, but the FW candidates chances increased where they did not face the competition of by their coalition partner at the state level. Since none of the results are statistically significant, this evidence is merely suggestive. But it clearly points in the direction suggested by the strategic alignment mechanism.

\section{Conclusion}

In this paper, we analyzed the impact of the global health crisis on political behavior by evaluating the early electoral effects of the spread of the coronavirus disease (COVID19), a natural disaster of unprecedented scale. Understanding the political implications of this crisis is important in its own right. In addition, we treat the global coronavirus pandemic as an opportunity to test several competing theoretical explanations that can link natural disasters and other calamities to electoral behavior.

We assessed the effect of the onset of the COVID-19 pandemic on electoral outcomes based on the case of Germany, one of the countries most heavily affected by the crisis.

\footnotetext{
${ }^{31}$ Column (6) in Table A9 repeats an analogous exercise for the elections of city mayors and county executives. Here we see that at this level, the FW lost votes in areas harder hit by the outbreak-a difference that is not statistically significant, however. In all of these places, the CSU also fielded candidates.
} 
Our data come from the local elections in the state of Bavaria, where local elections were held right at the beginning of the pandemic when there was still substantial variation in the extent to which individual counties and municipalities were affected by the outbreak. We provide evidence that shows that the disease spread across the state in a mostly haphazard fashion. This lack of a discernible pattern coupled with withincounty estimation of effects allow us to establish a causal effect of the spreading of the virus on electoral outcomes. Our results show that the crisis strongly and consistently benefited the dominant party, the CSU, and its candidates. At all levels of government up for election, CSU candidates did better in areas more strongly affected by the spread of the disease.

Our findings contradict theoretical claims that negative events reduce support for incumbent politicians. In the majority of counties and municipalities, CSU candidates were the incumbents and did well. Our results also provide little support for the other two mechanisms that we classify as driven by emotions: rally-'round-the-flag and outgroup hostility. The fact that we only find increased support for incumbents of the CSU, but not for incumbents of other parties, makes us doubt that what we are observing is a coming together behind the local executive. Moreover, the fact that the far-right party AfD lost votes makes us confident that what we are observing is not the expression of hostile sentiments. Our data do not provide much support for the evaluative, retrospective voting approach either. Overall, it seems that the elections happened at a point in time where it was still too early for voters to assess government performance, and our-admittedly rough-measures of crisis preparedness and response do not modify the effect of the COVID-19 outbreak on the electoral fortunes of the CSU candidates.

However, our findings provide evidence for a forward-looking strategic motivation among voters. Our results are best explained by a strategic alignment mechanism by which voters opt for the party best placed to help them through the crisis. Specifically, voters seem to have sought to align their local incumbents with the government in power at a higher level. Beyond the immediate case, our findings, therefore, provide case evidence for voters behaving in a rational, forward-looking way. We argue that this type of reasoning should be particularly prominent in situations of slowly-unfolding 
crises, where future developments arguably assume greater importance in voters' minds than in non-crisis times. Out paper, therefore, calls for a reassessment of the merit of theories of prospective voting, which have received little attention in recent research on political behavior.

Some words of caution are in order. Since we lack individual-level data, our evidence on the competing theoretical perspectives is not conclusive. For example, we cannot entirely rule out that our results are also driven by rally-'round-the-flag motivations targeted at a higher level of government-even though there is nothing in our data suggesting such a logic being at play. More importantly, we should stress that we are looking at voting behavior at the very onset of the pandemic. Dynamics might change as the crisis continues. For example, the fact that outgroup hostility did not appear to influence the elections might change as the number of fatalities continues to rise, and the negative economic effects of the crisis make themselves felt. Keeping these caveats in mind, our paper allows a glance at voting behavior at the very dawn of a global pandemic while highlighting the importance of strategic considerations among voters.

Our findings provide a cautionary tale for the functioning of democracy in times of crisis. While voters act strategically, their behavior seems to be oriented toward the short- and medium-term, notably the question of who will be best placed to help them in times of need. This means that politicians and parties that are already in a strong position gain in strength, to the detriment of smaller factions and electoral pluralism more generally. This increase in strength, in turn, may invite abuse. In several countries, incumbent politicians have used the outbreak of the virus as an opportunity to enlarge their powers. While this is a widespread phenomenon, our findings show that elections, which in principle should increase accountability, are an unlikely remedy. Rather than serving as a check, they may deepen the gap between incumbents of the dominant faction or party and the opposition. 


\section{References}

Abney, F. G. and L. B. Hill (1966, December). Natural Disasters as a Political Variable: The Effect of a Hurricane on an Urban Election. American Political Science Review 60(4), 974-981.

Achen, C. H. and L. M. Bartels (2012). Blind Retrospection: Why Shark Attacks Are Bad For Democracy. Center for the Study of Democratic Institutions. Working Paper 5-2013, 36.

Achen, C. H. and L. M. Bartels (2017). Democracy for realists: Why elections do not produce responsive government, Volume 4 . Princeton University Press.

Alesina, A. and F. Passarelli (2019). Loss Aversion in Politics. American Journal of Political Science 63(4), 936-947.

Alesina, A. and H. Rosenthal (1989). Partisan Cycles in Congressional Elections and the Macroeconomy. The American Political Science Review 83(2), 373-398.

Anselin, L. (1988). Spatial Econometrics: Methods and Models. Boston: Kluwer Academic Publishers.

Anselin, L. and S. Rey (1991). Properties of Tests for Spatial Dependence in Linear Regression Models. Geographical Analysis 23(2), 112-131.

Ansolabehere, S., M. Meredith, and E. Snowberg (2014). Mecro-Economic Voting: Local Information and Micro-Perceptions of the Macro-Economy. Economics E Politics 26(3), $380-410$.

Arceneaux, K. and R. M. Stein (2006, January). Who Is Held Responsible When Disaster Strikes? the Attribution of Responsibility for a Natural Disaster in an Urban Election. Journal of Urban Affairs 28(1), 43-53.

Arnold, F. and R. Freier (2016, March). Only conservatives are voting in the rain: Evidence from German local and state elections. Electoral Studies 41, 216-221.

Ashworth, S., E. Bueno de Mesquita, and A. Friedenberg (2018, January). Learning about Voter Rationality: Learning about Voter Rationality. American Journal of Political Science 62(1), 37-54. 
Baker, W. D. and J. R. Oneal (2016, July). Patriotism or Opinion Leadership?: The Nature and Origins of the "Rally 'Round the Flag" Effect. Journal of Conflict Resolution.

Barber, M., D. Gordon, R. Hill, and J. Price (2017/ed). Status Quo Bias in Ballot Wording. Journal of Experimental Political Science 4(2), 151-160.

Bechtel, M. M. and J. Hainmueller (2011, October). How Lasting Is Voter Gratitude? An Analysis of the Short- and Long-Term Electoral Returns to Beneficial Policy. American Journal of Political Science 55(4), 852-868.

Berrebi, C. and E. F. Klor (2008, August). Are Voters Sensitive to Terrorism? Direct Evidence from the Israeli Electorate. American Political Science Review 102(3), 279-301.

Bertrand, M., E. Duflo, and S. Mullainathan (2004, January). How Much Should We Trust Differences-In-Differences Estimates? The Quarterly Journal of Economics 119(1), 249-275.

Besley, T. (2006). Pincipled Agents? The Political Economy of Good Government. New York: Oxford University Press.

Bodet, M. A., M. Thomas, and C. Tessier (2016, September). Come hell or high water: An investigation of the effects of a natural disaster on a local election. Electoral Studies 43, 85-94.

Boittin, M., C. H. Mo, and S. Utych (2020). Can Natural Disasters Have a Rally 'Round the Flag Effect? The Political Consequences of Nepal's 2015 Earthquake. Working Paper, 51.

Bovan, K., B. Banai, and I. P. Banai (2018, April). Do Natural Disasters Affect Voting Behavior? Evidence from Croatian Floods. PLOS Currents Disasters.

Calvert, R. L. and J. A. Ferejohn (1983, June). Coattail Voting in Recent Presidential Elections. American Political Science Review 77(2), 407-419.

Campbell, A., P. E. Converse, W. E. Miller, and D. E. Stokes (1960). The American voter. Chicago: The University of Chicago Press.

Campbell, J. E. (1991). The Presidential Surge and its Midterm Decline in Congressional Elections , 1868-1988. The Journal of Politics 53(2), 477-487. 
Campbell, J. E. and J. A. Sumners (1990, June). Presidential Coattails in Senate Elections. American Political Science Review 84(2), 513-524.

Carlin, R. E., G. J. Love, and E. J. Zechmeister (2013, July). Natural Disaster and Democratic Legitimacy: The Public Opinion Consequences of Chile's 2010 Earthquake and Tsunami. Political Research Quarterly.

Cole, S., A. Healy, and E. Werker (2012, March). Do voters demand responsive governments? Evidence from Indian disaster relief. Journal of Development Economics 97(2), 167-181.

Conley, T. G. (1999). GMM Estimation with Cross Sectional Dependence. Journal of Econometrics 92(1), 1-45.

Converse, P. E. (1964). The nature of belief systems in mass publics (1964). In D. E. Apter (Ed.), Ideology and Its Discontents, pp. 206-261. New York: The Free Press of Glencoe.

Dinkel, R. (1977). Der Zusammenhang zwischen Bundes- und Landtagswahlergebnissen. Politische Vierteljahresschrift 18(2/3), 348-359.

Erikson, R. S. and M. G. Filippov (2001, December). Electoral Balancing in Federal and Sub-national Elections: The Case of Canada. Constitutional Political Economy 12(4), 313-331.

Fearon, J. D. (1999, September). Electoral Accountability and the Control of Politicians: Selecting Good Types versus Sanctioning Poor Performance. In A. Przeworski, S. Stokes, Susan Carol, S. C. Stokes, and B. Manin (Eds.), Democracy, Accountability, and Representation. Cambridge: Cambridge University Press. Google-Books-ID: aid08OpvF5gC.

Ferejohn, J. (1986). Incumbent Performance and Electoral Control. Public Choice 50(1/3), $5-25$.

Ferejohn, J. A. and R. L. Calvert (1984a). Presidential Coattails in Historical Perspective. American Journal of Political Science 28(1), 127-146. 
Ferejohn, J. A. and R. L. Calvert (1984b). Presidential Coattails in Historical Perspective. American Journal of Political Science 28(1), 127-146.

Fiorina, M. P. (1981). Retrospective Voting in American National Elections. New Haven/London: Yale University Press.

Fowler, A. and A. B. Hall (2018, October). Do Shark Attacks Influence Presidential Elections? Reassessing a Prominent Finding on Voter Competence. The Journal of Politics 80(4), 1423-1437.

Fowler, A. and B. P. Montagnes (2015, November). College football, elections, and false-positive results in observational research. Proceedings of the National Academy of Sciences 112(45), 13800-13804.

Fuchs, G. (2010). Kommunalpolitik im Freistaat Bayern. In A. Kost and H.-G. Wehling (Eds.), Kommunalpolitik in den deutschen Ländern: Eine Einführung, pp. 40-62. Wiesbaden: VS Verlag f $\tilde{A}^{1} / 4$ r Sozialwissenschaften.

Gasper, J. T. and A. Reeves (2011). Make It Rain? Retrospection and the Attentive Electorate in the Context of Natural Disasters. American Journal of Political Science 55(2), 340-355.

Getmansky, A. and T. Zeitzoff (2014, August). Terrorism and Voting: The Effect of Rocket Threat on Voting in Israeli Elections. American Political Science Review 108(3), 588-604.

Gomez, B. T., T. G. Hansford, and G. A. Krause (2007, August). The Republicans Should Pray for Rain: Weather, Turnout, and Voting in U.S. Presidential Elections. The Journal of Politics 69(3), 649-663.

Healy, A. and N. Malhotra (2009, August). Myopic Voters and Natural Disaster Policy. American Political Science Review 103(3), 387-406.

Healy, A. J., N. Malhotra, and C. H. Mo (2010, July). Irrelevant events affect voters' evaluations of government performance. Proceedings of the National Academy of Sciences 107(29), 12804-12809. 
Hopkins, D. J. (2018). The Increasingly United States. How and Why American Political Behavior Nationalized. Chicago: The University of Chicago Press.

Karol, D. and E. Miguel (2007). The Electoral Cost of War: Iraq Casualties and the 2004 U.S. Presidential Election. Journal of Politics 69(3), 633-648.

Kern, H. L. and J. Hainmueller (2006, June). Electoral balancing, divided government and 'midterm' loss in German elections. The Journal of Legislative Studies 12(2), 127149.

Key, V. (1966). The Responsible Electorate. Cambridge, Mass.: Harvard University Press.

Lambert, A. J., J. P. Schott, and L. Scherer (2011, December). Threat, Politics, and Attitudes: Toward a Greater Understanding of Rally-'Round-the-Flag Effects. Current Directions in Psychological Science 20(6), 343-348.

McNeill, W. H. (1976). Plagues and Peoples. London: Anchor Books.

Montalvo, J. G. (2011, November). Voting after the Bombings: A Natural Experiment on the Effect of Terrorist Attacks on Democratic Elections. Review of Economics and Statistics 93(4), 1146-1154.

Mueller, J. E. (1970, March). Presidential Popularity from Truman to Johnson1. American Political Science Review 64(1), 18-34.

Perry, M. and F. M. Schweitzer (2002). Antisemitism Myth and Hate from Antiquity to the Present. New York: Palgrave Macmillan.

Petrocik, J. R. (1996). Issue Ownership in Presidential Elections, with a 1980 Case Study. American Journal of Political Science 40(3), 825-850.

Rudolph, L. and A. Leininger (2020). Coattails and Spillover-Effects: QuasiExperimental Evidence from Concurrent Executive and Legislative Elections.

Ward, M. D. and K. S. Gleditsch (2008). Spatial Regression Models. Thousand Oaks: Sage Publications. 


\section{Appendix for}

\section{'Voting at the dawn of a global pandemic'}

\section{Table of Contents}

A Additional information

A.1 Summary statistics . . . . . . . . . . . . . . 1

A.2 Balance between affected and non-affected counties . . . . . . . . . 2

A.3 Pairwise correlations . . . . . . . . . . . . . . . 2

B Robustness checks 2

B.1 Trends in vote shares $\ldots \ldots \ldots \ldots \ldots \ldots$

B.2 Selection of control variables $\ldots \ldots \ldots \ldots$

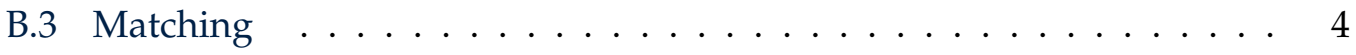

B.4 Spatial econometric tests . . . . . . . . . . . . 6

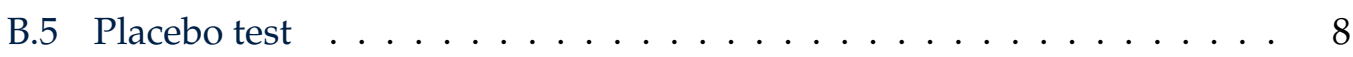

$\begin{array}{ll}\text { C Additional results } & 10\end{array}$

C.1 Results for all parties . . . . . . . . . . . . . . . . . . . 10

C.2 Testing for moderating effects of incumbency . . . . . . . . . . . . 11

C.3 Disaster preparedness and response . . . . . . . . . . . . . 12

$\begin{array}{ll}\text { D Auxiliary information } & 14\end{array}$

D.1 The prime minister's approval ratings . . . . . . . . . . . 14 


\section{A Additional information}

\section{A.1 Summary statistics}

Table A1: Summary statistics

\begin{tabular}{|c|c|c|c|c|c|}
\hline & Mean & SD & Min & Max & Count \\
\hline \multicolumn{6}{|l|}{ Counties } \\
\hline COVID-19 cases per 100,000 inhabitants & 5.77 & 6.63 & 0.00 & 41.31 & 96 \\
\hline COVID-19/100,000 (logged) & 1.51 & 0.93 & 0.00 & 3.75 & 96 \\
\hline More than 1 COVID-19 case in county & 0.72 & 0.45 & 0.00 & 1.00 & 96 \\
\hline Vote share CSU 2020 & 34.83 & 5.93 & 18.70 & 46.60 & 96 \\
\hline Vote share Greens 2020 & 15.87 & 5.81 & 5.20 & 32.50 & 96 \\
\hline Vote share SPD 2020 & 13.59 & 6.04 & 4.70 & 42.70 & 96 \\
\hline Vote share AfD 2020 & 5.44 & 1.65 & 1.40 & 9.20 & 83 \\
\hline$\Delta$ CSU vote share since 2014 & -5.19 & 3.16 & -17.80 & 2.10 & 96 \\
\hline$\Delta$ Greens vote share since 2014 & 5.70 & 2.68 & 1.00 & 15.00 & 96 \\
\hline$\Delta$ SPD vote share since 2014 & -6.54 & 3.13 & -21.50 & -0.70 & 96 \\
\hline$\Delta$ AfD vote share since 2014 & 5.29 & 1.85 & 0.40 & 9.20 & 83 \\
\hline Population density 2018 (10k/km2) & 0.47 & 0.70 & 0.07 & 4.74 & 96 \\
\hline$\Delta$ Population density $2013-18(10 / \mathrm{km} 2)$ & 2.08 & 3.69 & -0.21 & 20.49 & 96 \\
\hline Share foreign population 2017 (\%) & 10.65 & 4.61 & 3.60 & 25.50 & 96 \\
\hline$\Delta$ Share foreign pop $2012-17(\%)$ & 2.30 & 1.29 & -1.90 & 5.80 & 96 \\
\hline Unemployment rate 2019 (\%) & 3.34 & 1.07 & 1.50 & 6.10 & 96 \\
\hline$\Delta$ Unemployment rate $2013-19(\%)$ & -3.06 & 5.20 & -17.00 & 13.00 & 96 \\
\hline Aged 60 or above $2017(\%)$ & 27.32 & 2.34 & 21.00 & 33.60 & 96 \\
\hline$\Delta$ Aged 60 or above $2012-17(\%)$ & 0.99 & 1.01 & -2.00 & 2.70 & 96 \\
\hline Nr of employees 2017 (1k) & 13.43 & 12.04 & 1.50 & 97.76 & 96 \\
\hline$\Delta \mathrm{Nr}$ of employees $2012-17(1 \mathrm{k})$ & 1.02 & 1.52 & -2.49 & 9.33 & 96 \\
\hline \multicolumn{6}{|l|}{ Mayoralities } \\
\hline CSU vote share 2020 & 44.04 & 19.53 & 4.60 & 95.50 & 247 \\
\hline CSU share in prior election & 46.21 & 19.40 & 11.80 & 96.60 & 247 \\
\hline$\Delta$ CSU share since prior election & -2.18 & 18.65 & -67.90 & 53.80 & 247 \\
\hline CSU candidate incumbent & 0.38 & 0.49 & 0.00 & 1.00 & 247 \\
\hline Mayor (town) & 0.57 & 0.50 & 0.00 & 1.00 & 247 \\
\hline Chief executive county & 0.25 & 0.43 & 0.00 & 1.00 & 247 \\
\hline Mayor (city) & 0.19 & 0.39 & 0.00 & 1.00 & 247 \\
\hline
\end{tabular}




\section{A.2 Balance between affected and non-affected counties}

Table A2: Balance statistics

\begin{tabular}{lcccccc}
\hline & \multicolumn{2}{c}{ Overall } & \multicolumn{2}{c}{ Control } & \multicolumn{3}{c}{ Treatment } \\
& Mean & SD & Mean & SD & Mean & SD \\
\hline Population density 2018 $(10 \mathrm{k} / \mathrm{km} 2)$ & 0.47 & $(0.70)$ & 0.56 & $(0.53)$ & 0.43 & $(0.76)$ \\
$\Delta$ Population density 2013-18 $(10 / \mathrm{km} 2)$ & 2.08 & $(3.69)$ & 2.33 & $(3.03)$ & 1.99 & $(3.94)$ \\
Share foreign population 2017 $(\%)$ & 10.65 & $(4.61)$ & 11.46 & $(4.62)$ & 10.34 & $(4.61)$ \\
$\Delta$ Share foreign pop 2012-17 $(\%)$ & 2.30 & $(1.29)$ & 2.53 & $(1.32)$ & 2.21 & $(1.28)$ \\
Unemployment rate 2019 $(\%)$ & 3.34 & $(1.07)$ & 3.91 & $(1.03)$ & 3.12 & $(1.01)^{*}$ \\
$\Delta$ Unemployment rate 2013-19 $(\%)$ & -3.06 & $(5.20)$ & -3.93 & $(4.91)$ & -2.72 & $(5.31)$ \\
Aged 60 or above 2017 $(\%)$ & 27.32 & $(2.34)$ & 28.08 & $(2.20)$ & 27.02 & $(2.35)$ \\
$\Delta$ Aged 60 or above 2012-17 $(\%)$ & 0.99 & $(1.01)$ & 0.79 & $(1.17)$ & 1.07 & $(0.94)^{*}$ \\
Nr of employees 2017 $(1 \mathrm{k})$ & 13.43 & $(12.04)$ & 11.14 & $(9.25)$ & 14.33 & $(12.92)$ \\
$\Delta$ Nr of employees 2012-17 $(1 \mathrm{k})$ & 1.02 & $(1.52)$ & 0.92 & $(1.78)$ & 1.06 & $(1.42)$ \\
\hline $\mathrm{N}$ & \multicolumn{7}{c}{96} & 27 & & 69 & \\
\hline Balance statistics for counties with zero or one COVID-19 cases on 15 March 2020 (control group), or more than one
\end{tabular}
case on that date (treatment group). Differences that are significant at $\mathrm{p}<0.05$ marked with an asterisk (*).

\section{A.3 Pairwise correlations}

Table A3: Correlation of COVID-19 prevalence with control variables

\begin{tabular}{|c|c|c|c|c|c|c|c|c|c|c|c|}
\hline & COVID-19 & Popd18 & $\Delta$ Popd & Foreign17 & $\Delta$ Foreign & Unempl19 & $\Delta$ Unempl & Aged60+17 & $\Delta$ Aged60+ & Employ17 & $\Delta$ Employ \\
\hline COVID-19/100,000 (logged) & 1.00 & & & & & & & & & & \\
\hline Population density 2018 (10k/km2) & 0.04 & 1.00 & & & & & & & & & \\
\hline$\Delta$ Pop density $2013-18(10 / \mathrm{km} 2)$ & 0.04 & $0.93^{*}$ & 1.00 & & & & & & & & \\
\hline Share foreign population 2017 (\%) & 0.07 & $0.75^{*}$ & $0.76^{*}$ & 1.00 & & & & & & & \\
\hline$\Delta$ Share foreign pop 2012-17 (\%) & -0.03 & 0.18 & $0.34^{*}$ & $0.51^{*}$ & 1.00 & & & & & & \\
\hline Unemployment rate 2019 (\%) & -0.19 & $0.47^{*}$ & $0.40^{*}$ & $0.36^{*}$ & 0.18 & 1.00 & & & & & \\
\hline$\Delta$ Unemployment rate 2013-19 (\%) & 0.04 & $-0.49^{*}$ & $-0.43^{*}$ & $-0.33^{*}$ & -0.04 & -0.13 & 1.00 & & & & \\
\hline Aged 60 or above 2017 (\%) & $-0.23^{*}$ & $-0.33^{*}$ & $-0.44^{*}$ & $-0.45^{*}$ & $-0.30^{*}$ & $0.31^{*}$ & -0.06 & 1.00 & & & \\
\hline$\Delta$ Aged 60 or above $2012-17(\%)$ & -0.03 & $-0.58^{*}$ & $-0.69^{*}$ & $-0.84^{*}$ & $-0.59^{*}$ & $-0.35^{*}$ & $0.30^{*}$ & $0.35^{*}$ & 1.00 & & \\
\hline $\mathrm{Nr}$ of employees $2017(1 \mathrm{k})$ & 0.12 & $0.61^{*}$ & $0.56^{*}$ & $0.40^{*}$ & -0.09 & 0.00 & -0.10 & $-0.34^{*}$ & -0.19 & 1.00 & \\
\hline$\Delta \mathrm{Nr}$ of employees $2012-17(1 \mathrm{k})$ & 0.08 & 0.17 & $0.21^{*}$ & 0.12 & -0.07 & $-0.21^{*}$ & 0.10 & $-0.25^{*}$ & -0.03 & $0.62^{*}$ & 1.00 \\
\hline
\end{tabular}

\section{B Robustness checks}

\section{B.1 Trends in vote shares}


Figure A1: Testing parallel trends assumption
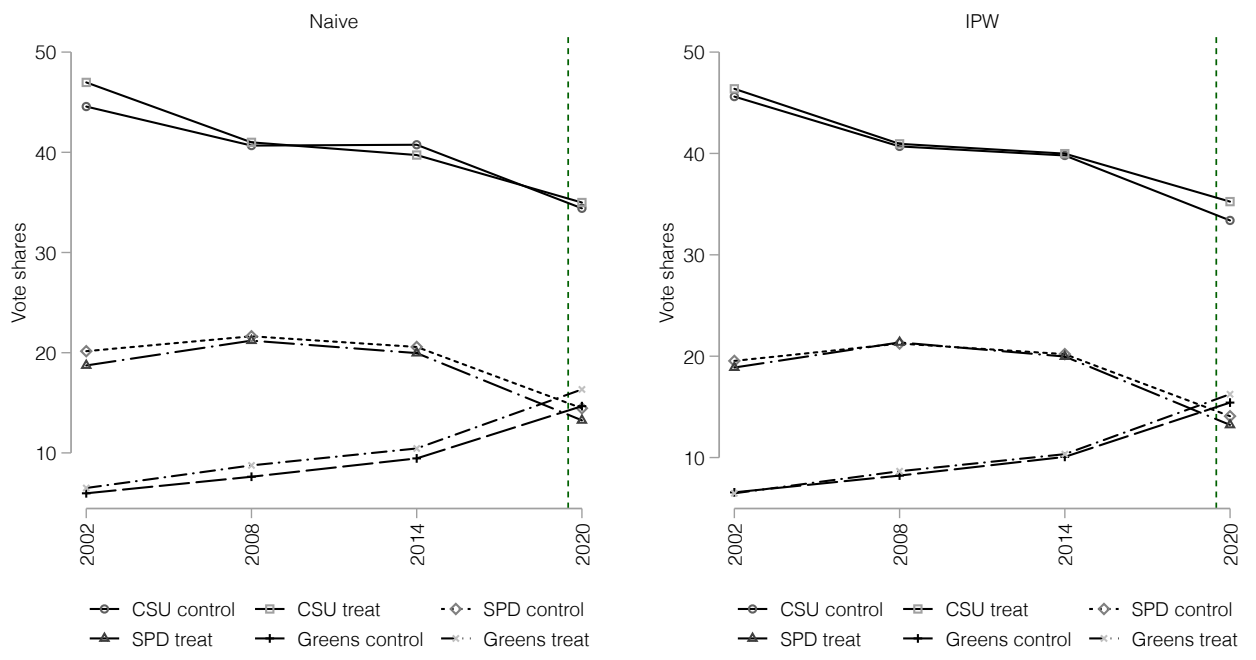

(a) Trends in vote shares of major parties in county council elections 2002-2008
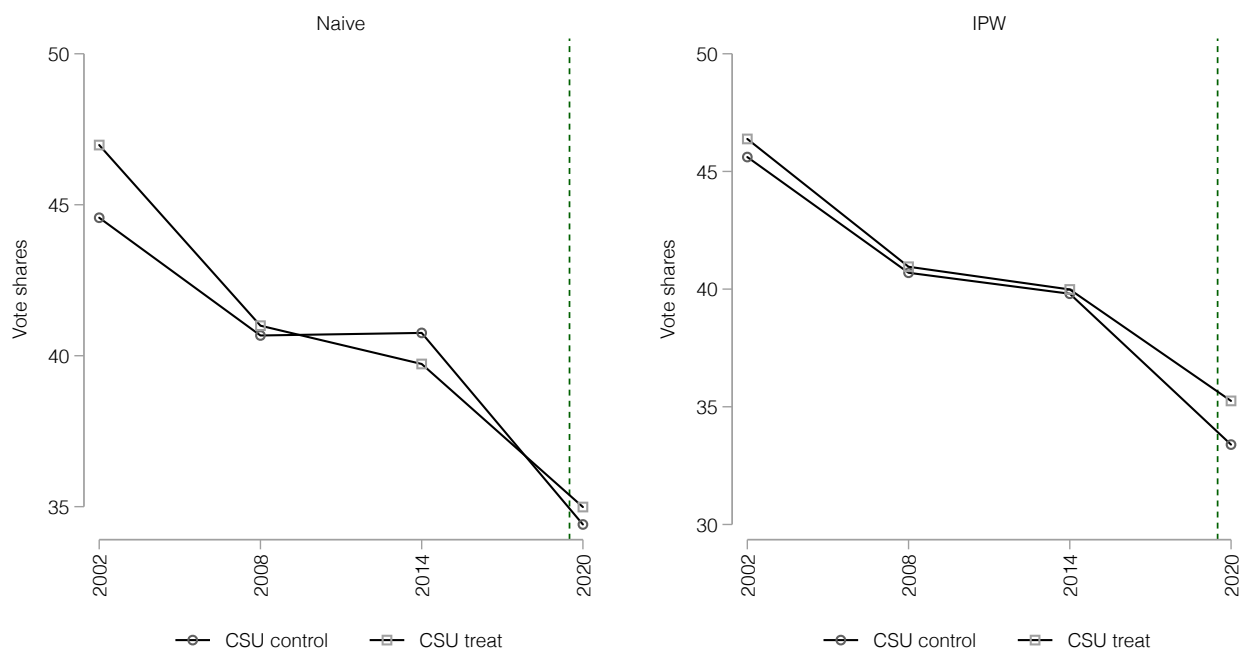

(b) Trends in CSU vote shares in county council elections 2002-2008

Note: The figure shows trends in average vote shares in county council elections over time for three major parties (Figure A1a) and separately for the CSU (Figure A1b) in counties heavily affected (treat) and unaffected (control) by the COVID-19 outbreak. As the naive pre-2014 trends are not parallel for the CSU vote shares, we also present inverse-probability-weighted estimates derived from a logistic regression of the treatment indicator on pre-2020 CSU vote shares. While the overall trend for CSU vote shares is negative, this trend is less pronounced in the treatment counties. The vertical lines indicate the approximate timing of the COVID-19 outbreak.

\section{B.2 Selection of control variables}

First, we test how sensitive our main result-the change in vote share for the CSU depending on the COVID-19 prevalence in county-is to the in- or exclusion of control 
variables. For this, we regress the outcome on all $2^{n}-1$ control variables using Equation 1. For the 10 included variables, this means running 1,023 separate regressions. Figure A2 depicts the distribution of estimated coefficients and corresponding $\mathrm{p}$-values for this exercise. As can be easily glanced, virtually all coefficients are positive and substantively meaningful, and $\mathrm{p}$-values cluster around $\mathrm{p}=0.02$ - well below conventional thresholds of statistical significance.

Figure A2: Coefficients and p-values for different combinations of control variables
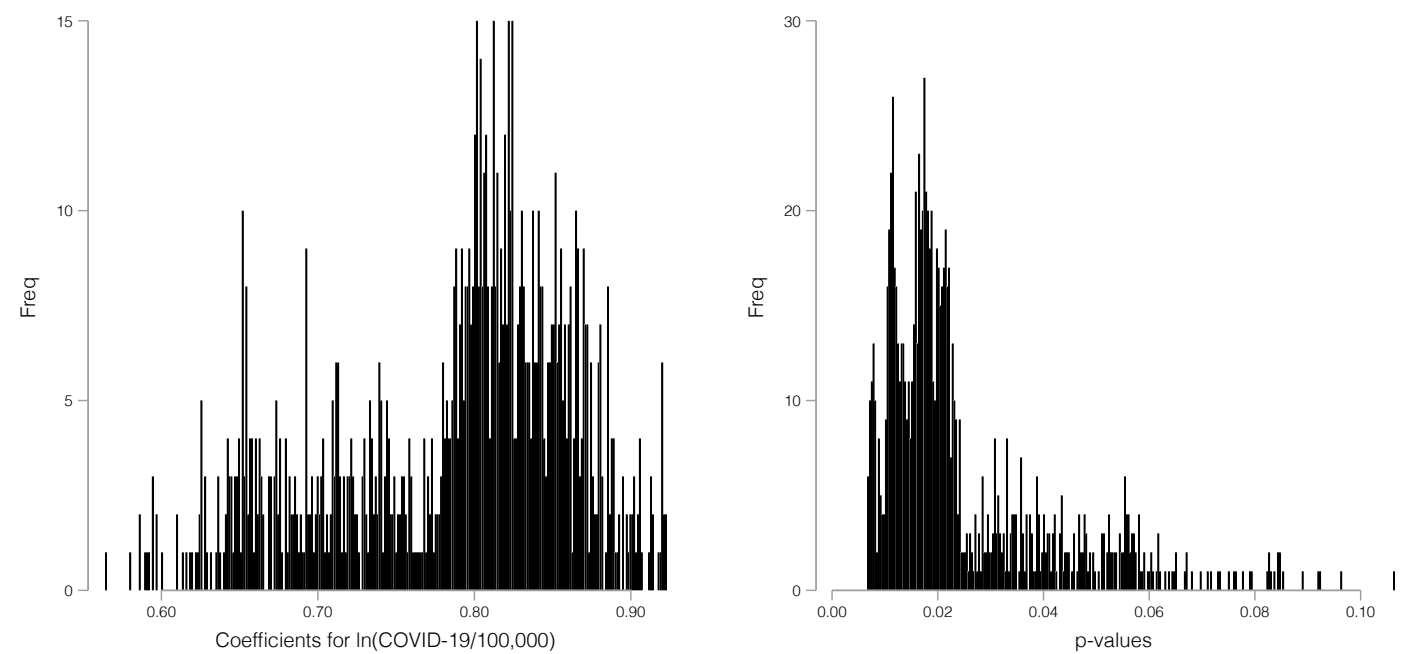

Note: The figure shows the regression coefficients and p-values for all possible combinations of control variables included in Equation 1.

\section{B.3 Matching}

Second, we use inverse probability weighting (IPW) and propensity score matching. Both methods use the propensity score, which measures the probability that a given county is affected by the COVID-19 outbreak. We use a logit model with the binary indicator for disease prevalence as dependent variable and our standard set of controls as predictors to estimate the propensity score. Table A4 Column (1) presents the results for a regression where observations are weighted using IPW. As can be seen, the overall effect size is very similar in terms of substantive and statistical significance to the unweighted model. 
Table A4: Regression models of CSU vote share on COVID-19 prevalence after inverse probability weighting and propensity score matching

\begin{tabular}{|c|c|c|c|c|c|}
\hline \multirow{3}{*}{$\begin{array}{l}\text { Method } \\
\text { Caliper }\end{array}$} & \multirow{3}{*}{$\begin{array}{c}\text { IPW } \\
(1)\end{array}$} & \multicolumn{4}{|c|}{ Propensity score matching } \\
\hline & & \multirow{2}{*}{$\begin{array}{c}0.15 \\
(2)\end{array}$} & \multirow{2}{*}{$\begin{array}{c}0.10 \\
(3)\end{array}$} & \multirow{2}{*}{$\begin{array}{c}0.05 \\
(4)\end{array}$} & \multirow{2}{*}{$\frac{0.025}{(5)}$} \\
\hline & & & & & \\
\hline COVID-19/100,000 (logged) & $\begin{array}{l}0.82^{*} \\
(0.36)\end{array}$ & $\begin{array}{l}1.14^{+} \\
(0.63)\end{array}$ & $\begin{array}{l}1.15^{*} \\
(0.59)\end{array}$ & $\begin{array}{l}1.02^{+} \\
(0.60)\end{array}$ & $\begin{array}{l}1.40^{+} \\
(0.83)\end{array}$ \\
\hline Population density 2018 (10k/km2) & $\begin{array}{l}1.66 \\
(2.48)\end{array}$ & $\begin{array}{c}2.50 \\
(7.59)\end{array}$ & $\begin{array}{c}1.61 \\
(6.60)\end{array}$ & $\begin{array}{c}3.13 \\
(8.54)\end{array}$ & $\begin{array}{c}4.07 \\
(10.39)\end{array}$ \\
\hline$\Delta$ Population density 2013-18 (10/km2) & $\begin{array}{l}-0.30 \\
(0.31)\end{array}$ & $\begin{array}{c}-0.62 \\
(0.97)\end{array}$ & $\begin{array}{c}-0.33 \\
(0.82)\end{array}$ & $\begin{array}{c}-0.55 \\
(1.29)\end{array}$ & $\begin{array}{l}-0.76 \\
(1.74)\end{array}$ \\
\hline Share foreign population 2017 (\%) & $\begin{array}{l}-0.50^{*} \\
(0.22)\end{array}$ & $\begin{array}{l}-0.58 \\
(0.45)\end{array}$ & $\begin{array}{l}-0.50 \\
(0.42)\end{array}$ & $\begin{array}{l}-0.59 \\
(0.48)\end{array}$ & $\begin{array}{l}-0.53 \\
(0.49)\end{array}$ \\
\hline$\Delta$ Share foreign pop 2012-17 (\%) & $\begin{array}{l}0.71^{*} \\
(0.35)\end{array}$ & $\begin{array}{c}0.89 \\
(0.72)\end{array}$ & $\begin{array}{c}0.78 \\
(0.70)\end{array}$ & $\begin{array}{c}0.63 \\
(0.90)\end{array}$ & $\begin{array}{c}1.46 \\
(1.46)\end{array}$ \\
\hline Unemployment rate $2019(\%)$ & $\begin{array}{c}0.25 \\
(0.54)\end{array}$ & $\begin{array}{c}0.20 \\
(0.94)\end{array}$ & $\begin{array}{c}0.18 \\
(1.04)\end{array}$ & $\begin{array}{c}0.03 \\
(1.04)\end{array}$ & $\begin{array}{c}0.68 \\
(1.32)\end{array}$ \\
\hline$\Delta$ Unemployment rate 2013-19 (\%) & $\begin{array}{l}-0.11 \\
(0.11)\end{array}$ & $\begin{array}{c}-0.11 \\
(0.16)\end{array}$ & $\begin{array}{c}-0.13 \\
(0.16)\end{array}$ & $\begin{array}{c}-0.14 \\
(0.17)\end{array}$ & $\begin{array}{l}-0.21 \\
(0.21)\end{array}$ \\
\hline Aged 60 or above $2017(\%)$ & $\begin{array}{c}0.06 \\
(0.26)\end{array}$ & $\begin{array}{l}-0.16 \\
(0.42)\end{array}$ & $\begin{array}{l}-0.14 \\
(0.41)\end{array}$ & $\begin{array}{l}-0.06 \\
(0.42)\end{array}$ & $\begin{array}{l}-0.15 \\
(0.55)\end{array}$ \\
\hline$\Delta$ Aged 60 or above $2012-17(\%)$ & $\begin{array}{l}-0.20 \\
(0.81)\end{array}$ & $\begin{array}{c}-0.47 \\
(1.36)\end{array}$ & $\begin{array}{c}0.07 \\
(1.22)\end{array}$ & $\begin{array}{c}-0.50 \\
(1.42)\end{array}$ & $\begin{array}{c}0.33 \\
(2.01)\end{array}$ \\
\hline Nr of employees 2017 (1k) & $\begin{array}{c}0.06 \\
(0.07)\end{array}$ & $\begin{array}{c}0.09 \\
(0.18)\end{array}$ & $\begin{array}{c}0.10 \\
(0.15)\end{array}$ & $\begin{array}{c}0.06 \\
(0.17)\end{array}$ & $\begin{array}{l}-0.03 \\
(0.24)\end{array}$ \\
\hline$\Delta \mathrm{Nr}$ of employees 2012-17 (1k) & $\begin{array}{l}-0.57 \\
(0.44)\end{array}$ & $\begin{array}{l}-0.86 \\
(1.00)\end{array}$ & $\begin{array}{c}-0.82 \\
(0.95)\end{array}$ & $\begin{array}{c}-0.72 \\
(0.96)\end{array}$ & $\begin{array}{c}-0.28 \\
(1.20)\end{array}$ \\
\hline Intercept & $\begin{array}{l}-5.76 \\
(7.07) \\
\end{array}$ & $\begin{array}{c}1.37 \\
(13.44)\end{array}$ & $\begin{array}{c}-0.64 \\
(12.98) \\
\end{array}$ & $\begin{array}{c}-0.25 \\
(12.41) \\
\end{array}$ & $\begin{array}{c}-3.16 \\
(13.44) \\
\end{array}$ \\
\hline $\mathrm{N}$ & 96 & 42 & 42 & 40 & 36 \\
\hline R2 & 0.31 & 0.40 & 0.39 & 0.41 & 0.50 \\
\hline
\end{tabular}

Further, Table A4 Colums (2) to (5) present results from regressions on samples derived using propensity score matching. We increasingly made the caliper used to enforce common support more punishing, starting with a caliper of 0.15 , and ending with a caliper of 0.025 . We note that effect sizes are higher than in the unmatched sample, even though three out of four results are only marginally significant at $\mathrm{p}<0.10$. This is likely due to the small sample sizes, however. Table A5 demonstrate that for the matched sample, all covariates are balanced. We here show results for matching with a caliper of 0.05, but the finding of perfect balance after matching holds for all caliper thresholds. 
Table A5: Balance statistics after propensity score matching

\begin{tabular}{lcccccc}
\hline & \multicolumn{2}{c}{ Overall } & \multicolumn{2}{c}{ Control } & \multicolumn{2}{c}{ Treatment } \\
& Mean & SD & Mean & SD & Mean & SD \\
\hline Population density 2018 $(10 \mathrm{k} / \mathrm{km} 2)$ & 0.48 & $(0.63)$ & 0.48 & $(0.51)$ & 0.48 & $(0.74)$ \\
$\Delta$ Population density 2013-18 $(10 / \mathrm{km} 2)$ & 2.30 & $(3.50)$ & 2.34 & $(3.16)$ & 2.27 & $(3.90)$ \\
Share foreign population 2017 $(\%)$ & 10.78 & $(4.79)$ & 10.82 & $(4.64)$ & 10.74 & $(5.05)$ \\
$\Delta$ Share foreign pop 2012-17 $(\%)$ & 2.45 & $(1.40)$ & 2.47 & $(1.35)$ & 2.44 & $(1.49)$ \\
Unemployment rate 2019 $(\%)$ & 3.64 & $(0.97)$ & 3.54 & $(0.89)$ & 3.74 & $(1.06)$ \\
$\Delta$ Unemployment rate 2013-19 $(\%)$ & -3.75 & $(5.61)$ & -3.50 & $(5.15)$ & -4.00 & $(6.16)$ \\
Aged 60 or above 2017 $(\%)$ & 27.87 & $(1.99)$ & 27.57 & $(1.88)$ & 28.16 & $(2.09)$ \\
$\Delta$ Aged 60 or above 2012-17 (\%) & 0.91 & $(1.11)$ & 0.91 & $(1.27)$ & 0.91 & $(0.95)$ \\
Nr of employees 2017 $(1 \mathrm{k})$ & 12.54 & $(9.42)$ & 12.72 & $(10.23)$ & 12.36 & $(8.81)$ \\
$\Delta$ Nr of employees 2012-17 $(1 \mathrm{k})$ & 1.05 & $(1.63)$ & 1.14 & $(2.02)$ & 0.96 & $(1.17)$ \\
\hline N & 40 & \multicolumn{7}{c}{20} & & 20 & \\
\hline Balance statistics for counties with zero or one COVID-19 cases on 15 March 2020 (control group), or more than one \\
case on that date (treatment group). Matched sample with resulting from propensity score matching with a caliper \\
of 0.05. Differences that are significant at $<<0.05$ marked with an asterisk (*). No differences statistically singificant.
\end{tabular}

\section{B.4 Spatial econometric tests}

In order to formally test for the presence or absence of spatial dependency, we conduct several spatial-econometric tests (Anselin, 1988; Ward and Gleditsch, 2008). All tests use the distance matrix $W$ that holds inverse-distance weights $\omega$ based on the distance (in degrees) between the centroids of all 96 counties in Bavaria. Table A6 present Moran's I and Geary's C values for the COVID-19 prevalence for the six days coming up to the election and for the election day. Here we see that none of the values save for Moran's I on the election day is statistically significant.

Table A6: Moran's I and Geary's C values for COVID-19 prevalence by day

\begin{tabular}{lcccc}
\hline Date & Moran's I & p-value & Geary's c & p-value \\
\hline 09 March 2020 & 0.021 & 0.142 & 0.948 & 0.310 \\
10 March 2020 & 0.009 & 0.231 & 1.023 & 0.437 \\
11 March 2020 & 0.007 & 0.269 & 1.017 & 0.448 \\
12 March 2020 & 0.016 & 0.175 & 0.984 & 0.444 \\
13 March 2020 & 0.026 & 0.109 & 0.947 & 0.296 \\
14 March 2020 & 0.022 & 0.139 & 0.933 & 0.214 \\
15 March 2020 & 0.030 & 0.099 & 0.929 & 0.218 \\
\hline
\end{tabular}

Second, in Table A7 we present three spatial-econometric versions of our main model (Equation 1). Column (1) presents the results from model that includes the spatially lagged dependent variable among the set of predictors, i.e. the change in CSU vote share for all other municipalities weighted with the inverse-distance weights $\omega$. 
Column (2) includes the results of a spatial error model, where the influence of nearby counties influences the estimate of the error terms only. In the absence of spatial dependency, this model converges to a standard OLS model. With spatial dependency, standard errors are corrected to take into account the iid violation. In the models, the presence of spatial dependency is indicated with the measures $\rho$ and $\lambda$, respectively.

Table A7: Spatial regression models of CSU vote share on COVID-19 prevalence

\begin{tabular}{|c|c|c|c|c|c|}
\hline Model & $\begin{array}{l}\text { Spatial Lag } \\
\text { (1) }\end{array}$ & $\begin{array}{l}\text { Spatial Error } \\
\text { (2) }\end{array}$ & $\begin{array}{l}\text { Conley } 10 \mathrm{~km} \\
\text { (3) }\end{array}$ & $\begin{array}{c}\text { Conley } 20 \mathrm{~km} \\
\text { (4) }\end{array}$ & $\begin{array}{c}\text { Conley } 50 \mathrm{~km} \\
\text { (5) }\end{array}$ \\
\hline COVID-19/100,000 (logged) & $\begin{array}{l}0.88^{*} \\
(0.31)\end{array}$ & $\begin{array}{l}0.88^{*} \\
(0.31)\end{array}$ & $\begin{array}{l}0.80^{*} \\
(0.31)\end{array}$ & $\begin{array}{l}0.80^{*} \\
(0.29)\end{array}$ & $\begin{array}{l}0.80^{*} \\
(0.25)\end{array}$ \\
\hline Population density 2018 (10k/km2) & $\begin{array}{c}0.41 \\
(1.85)\end{array}$ & $\begin{array}{c}0.31 \\
(1.81)\end{array}$ & $\begin{array}{c}0.75 \\
(1.68)\end{array}$ & $\begin{array}{c}0.75 \\
(1.31)\end{array}$ & $\begin{array}{c}0.75 \\
(1.10)\end{array}$ \\
\hline$\Delta$ Population density $2013-18(10 / \mathrm{km} 2)$ & $\begin{array}{l}-0.16 \\
(0.30)\end{array}$ & $\begin{array}{l}-0.15 \\
(0.30)\end{array}$ & $\begin{array}{l}-0.35 \\
(0.21)\end{array}$ & $\begin{array}{l}-0.35^{*} \\
(0.16)\end{array}$ & $\begin{array}{l}-0.35^{*} \\
(0.17)\end{array}$ \\
\hline Share foreign population 2017 (\%) & $\begin{array}{l}-0.44^{*} \\
(0.17)\end{array}$ & $\begin{array}{l}-0.43^{*} \\
(0.18)\end{array}$ & $\begin{array}{l}-0.49^{*} \\
(0.13)\end{array}$ & $\begin{array}{l}-0.49^{*} \\
(0.14)\end{array}$ & $\begin{array}{l}-0.49^{*} \\
(0.09)\end{array}$ \\
\hline$\Delta$ Share foreign pop 2012-17 (\%) & $\begin{array}{l}0.65^{*} \\
(0.32)\end{array}$ & $\begin{array}{l}0.62^{*} \\
(0.31)\end{array}$ & $\begin{array}{c}0.51 \\
(0.28)\end{array}$ & $\begin{array}{l}0.51^{*} \\
(0.24)\end{array}$ & $\begin{array}{c}0.51 \\
(0.26)\end{array}$ \\
\hline Unemployment rate 2019 (\%) & $\begin{array}{c}0.49 \\
(0.47)\end{array}$ & $\begin{array}{c}0.52 \\
(0.47)\end{array}$ & $\begin{array}{c}0.71 \\
(0.45)\end{array}$ & $\begin{array}{c}0.71 \\
(0.38)\end{array}$ & $\begin{array}{l}0.71^{*} \\
(0.29)\end{array}$ \\
\hline$\Delta$ Unemployment rate 2013-19 (\%) & $\begin{array}{l}-0.15 \\
(0.08)\end{array}$ & $\begin{array}{l}-0.15 \\
(0.08)\end{array}$ & $\begin{array}{l}-0.18^{*} \\
(0.08)\end{array}$ & $\begin{array}{l}-0.18^{*} \\
(0.07)\end{array}$ & $\begin{array}{l}-0.18^{*} \\
(0.06)\end{array}$ \\
\hline Aged 60 or above 2017 (\%) & $\begin{array}{l}-0.01 \\
(0.21)\end{array}$ & $\begin{array}{c}0.02 \\
(0.19)\end{array}$ & $\begin{array}{l}-0.18 \\
(0.10)\end{array}$ & $\begin{array}{l}-0.18^{*} \\
(0.09)\end{array}$ & $\begin{array}{l}-0.18^{*} \\
(0.07)\end{array}$ \\
\hline$\Delta$ Aged 60 or above $2012-17(\%)$ & $\begin{array}{l}-0.33 \\
(0.65)\end{array}$ & $\begin{array}{l}-0.30 \\
(0.65)\end{array}$ & $\begin{array}{l}-0.61 \\
(0.55)\end{array}$ & $\begin{array}{l}-0.61 \\
(0.58)\end{array}$ & $\begin{array}{l}-0.61 \\
(0.51)\end{array}$ \\
\hline Nr of employees 2017 (1k) & $\begin{array}{c}0.08 \\
(0.05)\end{array}$ & $\begin{array}{c}0.08 \\
(0.05)\end{array}$ & $\begin{array}{c}0.08 \\
(0.04)\end{array}$ & $\begin{array}{c}0.08 \\
(0.04)\end{array}$ & $\begin{array}{c}0.08 \\
(0.05)\end{array}$ \\
\hline$\Delta \mathrm{Nr}$ of employees 2012-17 (1k) & $\begin{array}{l}-0.61^{*} \\
(0.26)\end{array}$ & $\begin{array}{l}-0.61^{*} \\
(0.26)\end{array}$ & $\begin{array}{l}-0.61 \\
(0.33)\end{array}$ & $\begin{array}{l}-0.61 \\
(0.35)\end{array}$ & $\begin{array}{l}-0.61^{*} \\
(0.26)\end{array}$ \\
\hline Intercept & $\begin{array}{l}-3.96 \\
(6.69)\end{array}$ & $\begin{array}{l}-5.31 \\
(6.27)\end{array}$ & & & \\
\hline$\rho$ & $\begin{array}{c}0.0026 \\
(0.0027)\end{array}$ & & & & \\
\hline $\bar{\lambda}$ & & $\begin{array}{c}0.0015 \\
(0.0031)\end{array}$ & & & \\
\hline $\mathrm{N}$ & 96 & 96 & 96 & 96 & 96 \\
\hline
\end{tabular}

Closely related to this second model, Colums (3) to (5) present models where standard errors are calculated by the procedure due to Conley (1999). The idea here is very similar to the spatial error model in that standard errors are corrected for spatial autocorrelation-only that this is achieved by taking weighted averages of the covariances for pairs of observations that are close to each other. Conley's specification allows to set cutoff points beyond which the influence of neighboring counties is no longer taken into account. We here present three different cutoff points, 10, 20 and $50 \mathrm{~km}$. As shown in Table, none of the models indicates the prevalence of spatial dependency in 
our data, supporting the notion that the outbreak of the COVID-19 disease showed no distinct spatial pattern.

\section{B.5 Placebo test}

In order to provide further evidence that the difference in the change in CSU vote share 2014-2020 is unlikely to be driven by unobserved characteristics systematically favoring the CSU in areas affected by the COVID-19 outbreak, we present three placebo/falsification tests. We look at the election results of the last three elections that took place in Bavaria before the communal elections 2020. These were the European elections 2019, the state-level elections 2018, and the German general elections 2017. Replicating our design used in the analysis of the local elections, for each election we calculate the change in vote share from the preceding election for all 96 counties. We then regress this change score on our indicator for the spread of COVID-19. That is, we pretend that the outbreak had taken place shortly before the named elections. Table A8 presents the results of the this pseudo-experiment. We see that-as would be expected-in all cases effects sizes are close to zero and not statistically significant . 
Table A8: Placebo/falsification tests

\begin{tabular}{|c|c|c|c|}
\hline \multirow[t]{2}{*}{ Election } & Eur2019 & State2018 & General2017 \\
\hline & $\begin{array}{c}\Delta \mathrm{CSU}_{2014-19} \\
\text { (1) }\end{array}$ & $\begin{array}{c}\Delta \mathrm{CSU}_{2013-18} \\
\text { (2) }\end{array}$ & $\begin{array}{c}\Delta \mathrm{CSU}_{2013-17} \\
\text { (3) }\end{array}$ \\
\hline COVID-19/100,000 (logged) & $\begin{array}{c}0.32 \\
(0.28)\end{array}$ & $\begin{array}{l}-0.25 \\
(0.42)\end{array}$ & $\begin{array}{c}0.21 \\
(0.27)\end{array}$ \\
\hline Population density 2018 (10k/km2) & $\begin{array}{c}1.04 \\
(1.70)\end{array}$ & $\begin{array}{l}-0.05 \\
(2.69)\end{array}$ & $\begin{array}{c}0.35 \\
(1.73)\end{array}$ \\
\hline$\Delta$ Population density $2013-18(10 / \mathrm{km} 2)$ & $\begin{array}{l}-0.19 \\
(0.30)\end{array}$ & $\begin{array}{c}0.06 \\
(0.37)\end{array}$ & $\begin{array}{c}0.10 \\
(0.29)\end{array}$ \\
\hline Share foreign population 2017 (\%) & $\begin{array}{l}-0.09 \\
(0.14)\end{array}$ & $\begin{array}{l}-0.47^{*} \\
(0.16)\end{array}$ & $\begin{array}{l}-0.22 \\
(0.12)\end{array}$ \\
\hline$\Delta$ Share foreign pop 2012-17 (\%) & $\begin{array}{c}0.29 \\
(0.31)\end{array}$ & $\begin{array}{l}-0.22 \\
(0.39)\end{array}$ & $\begin{array}{l}-0.52 \\
(0.30)\end{array}$ \\
\hline Unemployment rate $2019(\%)$ & $\begin{array}{c}0.04 \\
(0.41)\end{array}$ & $\begin{array}{c}0.94 \\
(0.60)\end{array}$ & $\begin{array}{l}-0.41 \\
(0.38)\end{array}$ \\
\hline$\Delta$ Unemployment rate $2013-19(\%)$ & $\begin{array}{c}0.15 \\
(0.08)\end{array}$ & $\begin{array}{l}-0.20^{*} \\
(0.09)\end{array}$ & $\begin{array}{l}-0.25^{*} \\
(0.07)\end{array}$ \\
\hline Aged 60 or above $2017(\%)$ & $\begin{array}{c}0.06 \\
(0.17)\end{array}$ & $\begin{array}{c}0.11 \\
(0.23)\end{array}$ & $\begin{array}{c}0.25 \\
(0.17)\end{array}$ \\
\hline$\Delta$ Aged 60 or above $2012-17(\%)$ & $\begin{array}{l}-0.73 \\
(0.64)\end{array}$ & $\begin{array}{c}0.08 \\
(0.78)\end{array}$ & $\begin{array}{l}-0.54 \\
(0.62)\end{array}$ \\
\hline Nr of employees 2017 (1k) & $\begin{array}{c}0.01 \\
(0.04)\end{array}$ & $\begin{array}{c}0.11 \\
(0.06)\end{array}$ & $\begin{array}{c}0.05 \\
(0.04)\end{array}$ \\
\hline$\Delta \mathrm{Nr}$ of employees $2012-17(1 \mathrm{k})$ & $\begin{array}{l}-0.05 \\
(0.24)\end{array}$ & $\begin{array}{l}-0.64^{*} \\
(0.32)\end{array}$ & $\begin{array}{l}-0.40 \\
(0.27)\end{array}$ \\
\hline Intercept & $\begin{array}{l}-1.15 \\
(4.95)\end{array}$ & $\begin{array}{l}-12.05 \\
(7.19)\end{array}$ & $\begin{array}{c}-13.88^{*} \\
(5.02)\end{array}$ \\
\hline $\begin{array}{l}\mathrm{N} \\
\mathrm{R} 2\end{array}$ & $\begin{array}{c}96 \\
0.14\end{array}$ & $\begin{array}{c}96 \\
0.41\end{array}$ & $\begin{array}{c}96 \\
0.46\end{array}$ \\
\hline
\end{tabular}

OLS regression of the change in the CSU vote share in the indicated elections on the logged number of COVID-19 cases 2020. Bootstrapped standard errors in parentheses, resampling at county level, 1,000 repetitions, ${ }^{*} \mathrm{p}<0.05$ 


\section{Additional results}

\section{C.1 Results for all parties}

Table A9: Regression of change in party vote shares on COVID-19 prevalence (county elections)

\begin{tabular}{|c|c|c|c|c|c|c|c|c|c|c|}
\hline & $\begin{array}{c}\Delta \mathrm{CSU} \\
(1)\end{array}$ & $\begin{array}{c}\Delta \mathrm{CSU} \\
(2)\end{array}$ & $\begin{array}{c}\Delta \text { Greens } \\
\text { (3) }\end{array}$ & $\begin{array}{c}\Delta \text { Greens } \\
\text { (4) }\end{array}$ & $\begin{array}{c}\Delta \mathrm{SPD} \\
(5)\end{array}$ & $\begin{array}{c}\Delta S P D \\
(6)\end{array}$ & $\begin{array}{c}\Delta \mathrm{AfD} \\
(7)\end{array}$ & $\begin{array}{c}\Delta \mathrm{AfD} \\
(8)\end{array}$ & $\begin{array}{c}\Delta \mathrm{FW} \\
(9)\end{array}$ & $\begin{array}{c}\Delta \mathrm{FW} \\
(10)\end{array}$ \\
\hline COVID-19/100,000 (logged) & $\begin{array}{l}0.88^{*} \\
(0.34)\end{array}$ & & $\begin{array}{c}0.30 \\
(0.23)\end{array}$ & & $\begin{array}{c}-0.23 \\
(0.25)\end{array}$ & & $\begin{array}{l}-0.55^{*} \\
(0.23)\end{array}$ & & $\begin{array}{l}-2.06 \\
(1.52)\end{array}$ & \\
\hline COVID-19 × Year 2020 & & $\begin{array}{l}0.71^{*} \\
(0.34)\end{array}$ & & $\begin{array}{c}0.51 \\
(0.30)\end{array}$ & & $\begin{array}{l}-0.18 \\
(0.25)\end{array}$ & & $\begin{array}{c}-0.59^{*} \\
(0.21)\end{array}$ & & $\begin{array}{l}-2.14 \\
(1.40)\end{array}$ \\
\hline Population density 2018 (10k/km2) & $\begin{array}{c}0.24 \\
(2.10)\end{array}$ & & $\begin{array}{c}2.40 \\
(1.61)\end{array}$ & & $\begin{array}{l}-0.65 \\
(3.40)\end{array}$ & & $\begin{array}{l}-0.55 \\
(1.85)\end{array}$ & & $\begin{array}{c}3.58 \\
(8.06)\end{array}$ & \\
\hline$\Delta$ Population density $2013-18(10 / \mathrm{km} 2)$ & $\begin{array}{l}-0.20 \\
(0.30)\end{array}$ & $\begin{array}{l}-0.07 \\
(0.13)\end{array}$ & $\begin{array}{c}0.18 \\
(0.23)\end{array}$ & $\begin{array}{l}0.26^{*} \\
(0.09)\end{array}$ & $\begin{array}{c}0.06 \\
(0.65)\end{array}$ & $\begin{array}{l}-0.26 \\
(0.21)\end{array}$ & $\begin{array}{l}-0.08 \\
(0.29)\end{array}$ & $\begin{array}{c}0.01 \\
(0.10)\end{array}$ & $\begin{array}{l}-1.68 \\
(1.12)\end{array}$ & $\begin{array}{l}-0.27 \\
(0.44)\end{array}$ \\
\hline Share foreign population 2017 (\%) & $\begin{array}{l}-0.38^{*} \\
(0.16)\end{array}$ & & $\begin{array}{l}0.26^{*} \\
(0.12)\end{array}$ & & $\begin{array}{c}0.30 \\
(0.20)\end{array}$ & & $\begin{array}{l}-0.03 \\
(0.12)\end{array}$ & & $\begin{array}{c}0.11 \\
(0.72)\end{array}$ & \\
\hline$\Delta$ Share foreign pop $2012-17(\%)$ & $\begin{array}{c}0.57 \\
(0.35)\end{array}$ & $\begin{array}{c}0.27 \\
(0.30)\end{array}$ & $\begin{array}{l}-0.37 \\
(0.24)\end{array}$ & $\begin{array}{c}-0.30 \\
(0.30)\end{array}$ & $\begin{array}{l}-0.33 \\
(0.36)\end{array}$ & $\begin{array}{c}-0.01 \\
(0.30)\end{array}$ & $\begin{array}{c}0.16 \\
(0.21)\end{array}$ & $\begin{array}{c}0.16 \\
(0.16)\end{array}$ & $\begin{array}{c}0.26 \\
(1.28)\end{array}$ & $\begin{array}{c}0.54 \\
(1.12)\end{array}$ \\
\hline Unemployment rate 2019 (\%) & $\begin{array}{c}0.52 \\
(0.54)\end{array}$ & & $\begin{array}{l}-1.41^{*} \\
(0.38)\end{array}$ & & $\begin{array}{l}-0.39 \\
(0.58)\end{array}$ & & $\begin{array}{c}0.60 \\
(0.36)\end{array}$ & & $\begin{array}{c}3.37 \\
(2.06)\end{array}$ & \\
\hline$\Delta$ Unemployment rate $2013-19(\%)$ & $\begin{array}{l}-0.16 \\
(0.09)\end{array}$ & $\begin{array}{l}-0.13 \\
(0.07)\end{array}$ & $\begin{array}{l}-0.02 \\
(0.05)\end{array}$ & $\begin{array}{l}-0.14^{*} \\
(0.04)\end{array}$ & $\begin{array}{l}0.22^{*} \\
(0.09)\end{array}$ & $\begin{array}{c}0.18^{*} \\
(0.07)\end{array}$ & $\begin{array}{c}0.07 \\
(0.06)\end{array}$ & $\begin{array}{l}0.13^{*} \\
(0.04)\end{array}$ & $\begin{array}{l}-0.11 \\
(0.31)\end{array}$ & $\begin{array}{c}0.08 \\
(0.25)\end{array}$ \\
\hline Aged 60 or above 2017 (\%) & $\begin{array}{c}0.05 \\
(0.22)\end{array}$ & & $\begin{array}{c}0.25 \\
(0.18)\end{array}$ & & $\begin{array}{c}0.06 \\
(0.21)\end{array}$ & & $\begin{array}{l}-0.22 \\
(0.14)\end{array}$ & & $\begin{array}{l}-1.20 \\
(0.82)\end{array}$ & \\
\hline$\Delta$ Aged 60 or above $2012-17(\%)$ & $\begin{array}{l}-0.23 \\
(0.69)\end{array}$ & $\begin{array}{c}0.83 \\
(0.55)\end{array}$ & $\begin{array}{c}-0.07 \\
(0.50)\end{array}$ & $\begin{array}{c}-0.65 \\
(0.38)\end{array}$ & $\begin{array}{c}0.57 \\
(0.64)\end{array}$ & $\begin{array}{l}-0.39 \\
(0.45)\end{array}$ & $\begin{array}{c}0.22 \\
(0.50)\end{array}$ & $\begin{array}{c}0.24 \\
(0.32)\end{array}$ & $\begin{array}{c}0.29 \\
(3.12)\end{array}$ & $\begin{array}{c}-0.16 \\
(1.96)\end{array}$ \\
\hline Nr of employees 2017 (1k) & $\begin{array}{c}0.08 \\
(0.06)\end{array}$ & & $\begin{array}{l}-0.09^{*} \\
(0.04)\end{array}$ & & $\begin{array}{l}-0.12^{*} \\
(0.05)\end{array}$ & & $\begin{array}{c}0.03 \\
(0.03)\end{array}$ & & $\begin{array}{l}-0.06 \\
(0.21)\end{array}$ & \\
\hline$\Delta \mathrm{Nr}$ of employees 2012-17 (1k) & $\begin{array}{l}-0.62 \\
(0.40)\end{array}$ & $\begin{array}{l}-0.49 \\
(0.36)\end{array}$ & $\begin{array}{c}0.01 \\
(0.18)\end{array}$ & $\begin{array}{l}-0.08 \\
(0.15)\end{array}$ & $\begin{array}{c}0.50 \\
(0.34)\end{array}$ & $\begin{array}{c}0.18 \\
(0.30)\end{array}$ & $\begin{array}{l}-0.07 \\
(0.18)\end{array}$ & $\begin{array}{l}-0.06 \\
(0.14)\end{array}$ & $\begin{array}{c}0.55 \\
(1.20)\end{array}$ & $\begin{array}{l}-0.18 \\
(0.91)\end{array}$ \\
\hline Year 2020 & & $\begin{array}{l}-7.47^{*} \\
(1.39)\end{array}$ & & $\begin{array}{l}5.36^{*} \\
(1.17)\end{array}$ & & $\begin{array}{c}-4.95^{*} \\
(1.35)\end{array}$ & & $\begin{array}{l}6.03^{*} \\
(0.83)\end{array}$ & & $\begin{array}{c}6.71 \\
(5.13)\end{array}$ \\
\hline Intercept & $\begin{array}{l}-7.39 \\
(5.91)\end{array}$ & $\begin{array}{c}29.59 \\
(19.23)\end{array}$ & $\begin{array}{c}0.96 \\
(4.87)\end{array}$ & $\begin{array}{c}23.98 \\
(14.13)\end{array}$ & $\begin{array}{l}-7.74 \\
(5.99)\end{array}$ & $\begin{array}{c}33.32 \\
(20.73)\end{array}$ & $\begin{array}{l}10.13^{*} \\
(4.07)\end{array}$ & $\begin{array}{l}-12.15 \\
(12.53)\end{array}$ & $\begin{array}{c}27.99 \\
(23.63)\end{array}$ & $\begin{array}{c}22.07 \\
(71.15)\end{array}$ \\
\hline $\mathrm{N}$ & 96 & 192 & 96 & 192 & 96 & 192 & 83 & 166 & 93 & 186 \\
\hline $\mathrm{N}$ counties & 96 & 96 & 96 & 96 & 96 & 96 & 83 & 83 & 93 & 93 \\
\hline $\mathrm{R} 2$ & 0.27 & 0.95 & 0.63 & 0.97 & 0.29 & 0.99 & 0.29 & 0.93 & 0.10 & 0.68 \\
\hline
\end{tabular}




\section{C.2 Testing for moderating effects of incumbency}

Table A10: Effect of incumbency (elections of mayors and county executives)

\begin{tabular}{|c|c|c|c|c|c|c|c|}
\hline \multirow{2}{*}{$\begin{array}{l}\text { Model } \\
\text { Outcome }\end{array}$} & \multirow{2}{*}{$\frac{\text { Change }}{\Delta \mathrm{CSU}}$} & \multirow{2}{*}{$\frac{\mathrm{DiD}}{\Delta \mathrm{CSU}}$} & \multicolumn{5}{|c|}{ Change } \\
\hline & & & $\begin{array}{l}\Delta \text { All inc. } \\
(3)\end{array}$ & $\underset{(4)}{\Delta \mathrm{CSU} \text { inc. }}$ & $\begin{array}{l}\Delta \mathrm{SPD} \text { inc. } \\
\quad(5)\end{array}$ & $\begin{array}{l}\Delta \mathrm{FW} \text { inc. } \\
\quad(6)\end{array}$ & $\begin{array}{l}\Delta \text { Others inc. } \\
\quad(7)\end{array}$ \\
\hline COVID-19/100,000 (logged) & & & $\begin{array}{l}1.06 \\
(1.65)\end{array}$ & $\begin{array}{l}4.64^{*} \\
(2.00)\end{array}$ & $\begin{array}{l}-4.50 \\
(7.28)\end{array}$ & $\begin{array}{c}-6.41 \\
(22.14)\end{array}$ & $\begin{array}{l}-0.08 \\
(5.25)\end{array}$ \\
\hline COVID-19 $\times$ Incumbent & $\begin{array}{c}2.12 \\
(2.66)\end{array}$ & & & & & & \\
\hline COVID-19 $\times$ Year $2020 \times$ Incumbent & & $\begin{array}{c}2.09 \\
(2.66)\end{array}$ & & & & & \\
\hline Population density 2018 (10k/km2) & $\begin{array}{l}-8.20 \\
(7.96)\end{array}$ & & $\begin{array}{l}-22.64 \\
(13.41)\end{array}$ & $\begin{array}{l}-16.03 \\
(21.98)\end{array}$ & $\begin{array}{l}-14.61 \\
(46.03)\end{array}$ & $\begin{array}{c}24.74 \\
(925.29)\end{array}$ & $\begin{array}{l}-36.81 \\
(66.89)\end{array}$ \\
\hline$\Delta$ Population density $2013-18(10 / \mathrm{km} 2)$ & $\begin{array}{l}-0.19 \\
(1.39)\end{array}$ & $\begin{array}{l}-0.70 \\
(0.45)\end{array}$ & $\begin{array}{l}2.98 \\
(2.33)\end{array}$ & $\begin{array}{c}0.98 \\
(4.61)\end{array}$ & $\begin{array}{l}3.38 \\
(8.38)\end{array}$ & $\begin{array}{c}-22.02 \\
(194.76)\end{array}$ & $\begin{array}{c}8.12 \\
(12.21)\end{array}$ \\
\hline Share foreign population 2017 (\%) & $\begin{array}{l}-0.72 \\
(0.69)\end{array}$ & & $\begin{array}{c}1.32 \\
(1.05)\end{array}$ & $\begin{array}{c}0.63 \\
(1.46)\end{array}$ & $\begin{array}{c}3.03 \\
(3.92)\end{array}$ & $\begin{array}{c}2.38 \\
(27.91)\end{array}$ & $\begin{array}{c}4.09 \\
(3.15)\end{array}$ \\
\hline$\Delta$ Share foreign pop 2012-17 (\%) & $\begin{array}{c}0.84 \\
(1.98)\end{array}$ & $\begin{array}{c}0.35 \\
(1.74)\end{array}$ & $\begin{array}{l}-1.07 \\
(2.22)\end{array}$ & $\begin{array}{l}-0.68 \\
(3.21)\end{array}$ & $\begin{array}{l}-3.59 \\
(6.43)\end{array}$ & $\begin{array}{c}3.98 \\
(36.71)\end{array}$ & $\begin{array}{l}-5.03 \\
(7.87)\end{array}$ \\
\hline Unemployment rate 2019 (\%) & $\begin{array}{c}2.83 \\
(2.00)\end{array}$ & & $\begin{array}{l}2.06 \\
(2.61)\end{array}$ & $\begin{array}{c}4.90 \\
(3.50)\end{array}$ & $\begin{array}{l}-0.19 \\
(9.34)\end{array}$ & $\begin{array}{c}10.75 \\
(58.75)\end{array}$ & $\begin{array}{l}-0.15 \\
(8.93)\end{array}$ \\
\hline$\Delta$ Unemployment rate $2013-19(\%)$ & $\begin{array}{l}-1.08^{*} \\
(0.32)\end{array}$ & $\begin{array}{c}-0.78^{*} \\
(0.28)\end{array}$ & $\begin{array}{l}-0.76 \\
(0.44)\end{array}$ & $\begin{array}{l}-0.82 \\
(0.52)\end{array}$ & $\begin{array}{c}0.99 \\
(1.73)\end{array}$ & $\begin{array}{c}-2.25 \\
(10.39)\end{array}$ & $\begin{array}{l}-0.10 \\
(1.44)\end{array}$ \\
\hline Aged 60 or above 2017 (\%) & $\begin{array}{l}-0.39 \\
(0.77)\end{array}$ & & $\begin{array}{c}0.61 \\
(0.99)\end{array}$ & $\begin{array}{l}-0.24 \\
(1.40)\end{array}$ & $\begin{array}{c}2.44 \\
(3.26)\end{array}$ & $\begin{array}{c}-1.75 \\
(24.21)\end{array}$ & $\begin{array}{c}2.19 \\
(3.24)\end{array}$ \\
\hline$\Delta$ Aged 60 or above $2012-17(\%)$ & $\begin{array}{l}-1.11 \\
(2.70)\end{array}$ & $\begin{array}{c}0.61 \\
(1.86)\end{array}$ & $\begin{array}{c}5.72 \\
(3.79)\end{array}$ & $\begin{array}{c}7.12 \\
(5.44)\end{array}$ & $\begin{array}{c}3.04 \\
(14.95)\end{array}$ & $\begin{array}{l}-7.51 \\
(50.65)\end{array}$ & $\begin{array}{c}14.44 \\
(11.00)\end{array}$ \\
\hline Nr of employees 2017 (1k) & $\begin{array}{l}0.38^{*} \\
(0.19)\end{array}$ & & $\begin{array}{c}0.13 \\
(0.27)\end{array}$ & $\begin{array}{l}0.69^{*} \\
(0.31)\end{array}$ & $\begin{array}{l}-0.31 \\
(0.78)\end{array}$ & $\begin{array}{c}0.46 \\
(4.93)\end{array}$ & $\begin{array}{l}-0.57 \\
(0.86)\end{array}$ \\
\hline$\Delta \mathrm{Nr}$ of employees 2012-17 (1k) & $\begin{array}{l}-0.72 \\
(1.34)\end{array}$ & $\begin{array}{c}0.33 \\
(0.96)\end{array}$ & $\begin{array}{l}-0.19 \\
(1.52)\end{array}$ & $\begin{array}{l}-1.19 \\
(2.21)\end{array}$ & $\begin{array}{c}1.21 \\
(3.55)\end{array}$ & $\begin{array}{c}-0.92 \\
(15.75)\end{array}$ & $\begin{array}{l}-2.56 \\
(5.38)\end{array}$ \\
\hline COVID-19 (const. term) & $\begin{array}{c}3.10 \\
(1.83)\end{array}$ & $\begin{array}{l}18.83^{*} \\
(5.70)\end{array}$ & & & & & \\
\hline Incumbent (const. term) & $\begin{array}{c}6.64 \\
(4.96)\end{array}$ & & & & & & \\
\hline Year 2020 (const. term) & & $\begin{array}{c}-12.83^{*} \\
(5.62)\end{array}$ & & & & & \\
\hline COVID-19 × Year 2020 (const. term) & & $\begin{array}{c}2.45 \\
(1.67)\end{array}$ & & & & & \\
\hline COVID-19 $\times$ Incumbent (const. term) & & $\begin{array}{l}-0.24 \\
(2.89)\end{array}$ & & & & & \\
\hline COVID-19 × Year 2020 (const.term) & & $\begin{array}{c}6.37 \\
(4.90)\end{array}$ & & & & & \\
\hline Intercept & $\begin{array}{c}-6.74 \\
(22.70)\end{array}$ & $\begin{array}{c}61.64 \\
(64.81)\end{array}$ & $\begin{array}{l}-47.10 \\
(30.10)\end{array}$ & $\begin{array}{l}-37.62 \\
(43.05)\end{array}$ & $\begin{array}{l}-90.42 \\
(91.91)\end{array}$ & $\begin{array}{c}2.13 \\
(526.66)\end{array}$ & $\begin{array}{c}-96.97 \\
(104.01)\end{array}$ \\
\hline $\mathrm{N}$ & 247 & 494 & 265 & 126 & 55 & 32 & 52 \\
\hline R2 & 0.13 & 0.58 & 0.03 & 0.11 & 0.05 & 0.23 & 0.15 \\
\hline
\end{tabular}




\section{C.3 Disaster preparedness and response}

Table A11: Interaction with disaster preparedness and early response

\begin{tabular}{|c|c|c|c|c|c|c|}
\hline \multirow{3}{*}{$\begin{array}{l}\text { Type } \\
\text { Outcome }\end{array}$} & \multirow{2}{*}{\multicolumn{2}{|c|}{$\begin{array}{c}\text { Counties } \\
\text { CSU }\end{array}$}} & \multicolumn{4}{|c|}{ Mayoralities } \\
\hline & & & \multicolumn{2}{|c|}{ CSU inc } & \multicolumn{2}{|c|}{ All inc } \\
\hline & (1) & (2) & (3) & (4) & (5) & (6) \\
\hline COVID-19 $\times \Delta$ Hospital beds 2012-17 & $\begin{array}{c}0.05 \\
(0.04)\end{array}$ & & $\begin{array}{l}-0.10 \\
(0.21)\end{array}$ & & $\begin{array}{c}0.27 \\
(0.26)\end{array}$ & \\
\hline COVID-19 $\times$ Test/information center & & $\begin{array}{c}0.03 \\
(0.98)\end{array}$ & & $\begin{array}{l}-3.27 \\
(5.22)\end{array}$ & & $\begin{array}{c}5.87 \\
(7.89)\end{array}$ \\
\hline COVID-19/100,000 (logged) (const. term) & $\begin{array}{l}0.86^{*} \\
(0.36)\end{array}$ & $\begin{array}{l}0.86^{*} \\
(0.38)\end{array}$ & $\begin{array}{l}3.24^{*} \\
(1.53)\end{array}$ & $\begin{array}{l}3.47^{*} \\
(1.54)\end{array}$ & $\begin{array}{c}1.51 \\
(2.00)\end{array}$ & $\begin{array}{c}0.88 \\
(2.19)\end{array}$ \\
\hline Hospital beds 2012-17 (const. term) & $\begin{array}{l}-0.04 \\
(0.08)\end{array}$ & & $\begin{array}{c}0.13 \\
(0.40)\end{array}$ & & $\begin{array}{l}-0.04 \\
(0.47)\end{array}$ & \\
\hline Test/information center (const. term) & & $\begin{array}{l}-0.10 \\
(2.15)\end{array}$ & & $\begin{array}{c}8.92 \\
(11.58)\end{array}$ & & $\begin{array}{l}-14.55 \\
(18.12)\end{array}$ \\
\hline Hospital beds 2012 (100s) & $\begin{array}{c}0.09 \\
(0.09)\end{array}$ & & $\begin{array}{l}-0.37 \\
(0.23)\end{array}$ & & $\begin{array}{c}0.17 \\
(0.37)\end{array}$ & \\
\hline Population density 2018 (10k/km2) & $\begin{array}{l}-0.28 \\
(2.30)\end{array}$ & $\begin{array}{c}0.49 \\
(2.24)\end{array}$ & $\begin{array}{l}-1.61 \\
(8.55)\end{array}$ & $\begin{array}{l}-5.20 \\
(8.84)\end{array}$ & $\begin{array}{l}-18.78 \\
(14.37)\end{array}$ & $\begin{array}{l}-22.46 \\
(13.13)\end{array}$ \\
\hline$\Delta$ Population density $2013-18(10 / \mathrm{km} 2)$ & $\begin{array}{l}-0.31 \\
(0.32)\end{array}$ & $\begin{array}{l}-0.27 \\
(0.33)\end{array}$ & $\begin{array}{l}-0.76 \\
(1.31)\end{array}$ & $\begin{array}{l}-0.80 \\
(1.31)\end{array}$ & $\begin{array}{c}2.52 \\
(2.22)\end{array}$ & $\begin{array}{c}3.08 \\
(2.21)\end{array}$ \\
\hline Share foreign population 2017 (\%) & $\begin{array}{l}-0.41^{*} \\
(0.17)\end{array}$ & $\begin{array}{l}-0.40^{*} \\
(0.17)\end{array}$ & $\begin{array}{l}-0.58 \\
(0.78)\end{array}$ & $\begin{array}{l}-0.57 \\
(0.83)\end{array}$ & $\begin{array}{c}1.01 \\
(1.36)\end{array}$ & $\begin{array}{c}1.18 \\
(1.38)\end{array}$ \\
\hline$\Delta$ Share foreign pop $2012-17(\%)$ & $\begin{array}{c}0.62 \\
(0.38)\end{array}$ & $\begin{array}{c}0.55 \\
(0.36)\end{array}$ & $\begin{array}{c}0.84 \\
(2.00)\end{array}$ & $\begin{array}{c}0.82 \\
(1.98)\end{array}$ & $\begin{array}{l}-0.91 \\
(2.29)\end{array}$ & $\begin{array}{l}-0.87 \\
(2.24)\end{array}$ \\
\hline Unemployment rate 2019 (\%) & $\begin{array}{c}0.59 \\
(0.54)\end{array}$ & $\begin{array}{c}0.48 \\
(0.57)\end{array}$ & $\begin{array}{c}2.11 \\
(2.08)\end{array}$ & $\begin{array}{c}2.47 \\
(2.04)\end{array}$ & $\begin{array}{c}1.51 \\
(3.10)\end{array}$ & $\begin{array}{c}2.00 \\
(3.01)\end{array}$ \\
\hline$\Delta$ Unemployment rate 2013-19 (\%) & $\begin{array}{l}-0.15 \\
(0.09)\end{array}$ & $\begin{array}{l}-0.15 \\
(0.09)\end{array}$ & $\begin{array}{l}-0.97^{*} \\
(0.33)\end{array}$ & $\begin{array}{l}-0.95^{*} \\
(0.37)\end{array}$ & $\begin{array}{l}-0.60 \\
(0.51)\end{array}$ & $\begin{array}{l}-0.81 \\
(0.50)\end{array}$ \\
\hline Aged 60 or above $2017(\%)$ & $\begin{array}{c}0.04 \\
(0.23)\end{array}$ & $\begin{array}{c}0.06 \\
(0.23)\end{array}$ & $\begin{array}{l}-0.24 \\
(0.80)\end{array}$ & $\begin{array}{l}-0.37 \\
(0.78)\end{array}$ & $\begin{array}{c}0.64 \\
(1.17)\end{array}$ & $\begin{array}{c}0.60 \\
(1.17)\end{array}$ \\
\hline$\Delta$ Aged 60 or above $2012-17(\%)$ & $\begin{array}{l}-0.49 \\
(0.75)\end{array}$ & $\begin{array}{l}-0.40 \\
(0.74)\end{array}$ & $\begin{array}{l}-0.56 \\
(2.61)\end{array}$ & $\begin{array}{l}-0.52 \\
(2.65)\end{array}$ & $\begin{array}{c}5.73 \\
(4.20)\end{array}$ & $\begin{array}{c}5.63 \\
(4.21)\end{array}$ \\
\hline Nr of employees 2017 (1k) & $\begin{array}{c}0.05 \\
(0.06)\end{array}$ & $\begin{array}{c}0.09 \\
(0.06)\end{array}$ & $\begin{array}{l}0.50^{*} \\
(0.23)\end{array}$ & $\begin{array}{c}0.31 \\
(0.22)\end{array}$ & $\begin{array}{l}-0.01 \\
(0.36)\end{array}$ & $\begin{array}{c}0.16 \\
(0.37)\end{array}$ \\
\hline$\Delta \mathrm{Nr}$ of employees 2012-17 (1k) & $\begin{array}{l}-0.56 \\
(0.39)\end{array}$ & $\begin{array}{l}-0.63 \\
(0.42)\end{array}$ & $\begin{array}{l}-0.58 \\
(1.28)\end{array}$ & $\begin{array}{l}-0.24 \\
(1.24)\end{array}$ & $\begin{array}{c}0.25 \\
(1.48)\end{array}$ & $\begin{array}{l}-0.48 \\
(1.57)\end{array}$ \\
\hline Intercept & $\begin{array}{l}-6.54 \\
(6.30)\end{array}$ & $\begin{array}{l}-7.01 \\
(6.15)\end{array}$ & $\begin{array}{c}-7.21 \\
(22.20)\end{array}$ & $\begin{array}{c}-4.71 \\
(22.29)\end{array}$ & $\begin{array}{l}-44.24 \\
(31.68)\end{array}$ & $\begin{array}{l}-45.20 \\
(32.24)\end{array}$ \\
\hline $\mathrm{N}$ & 96 & 96 & 247 & 247 & 265 & 265 \\
\hline R2 & 0.30 & 0.27 & 0.07 & 0.06 & 0.05 & 0.04 \\
\hline
\end{tabular}


Table A12: FW success in the presence or absence of competition by CSU candidates

\begin{tabular}{|c|c|c|c|c|}
\hline \multirow{3}{*}{ CSU competition } & \multicolumn{2}{|c|}{ Vote shares } & \multicolumn{2}{|c|}{ Electoral success } \\
\hline & Yes & No & Yes & No \\
\hline & $(1)$ & (2) & (3) & (4) \\
\hline School closure due to COVID-19 case & $\begin{array}{l}-1.73 \\
(3.92)\end{array}$ & $\begin{array}{c}7.87 \\
(22.38)\end{array}$ & $\begin{array}{c}0.43 \\
(0.39)\end{array}$ & $\begin{array}{l}-0.16 \\
(0.19)\end{array}$ \\
\hline Population density 2018 (10k/km2) & $\begin{array}{c}6.57 \\
(6.02)\end{array}$ & $\begin{array}{c}-17.13 \\
(40.55)\end{array}$ & $\begin{array}{l}-0.54 \\
(0.56)\end{array}$ & $\begin{array}{c}0.26 \\
(0.30)\end{array}$ \\
\hline$\Delta$ Population density 2013-18 (10/km2) & $\begin{array}{l}-0.58 \\
(0.88)\end{array}$ & $\begin{array}{l}-1.74 \\
(4.23)\end{array}$ & $\begin{array}{c}0.01 \\
(0.09)\end{array}$ & $\begin{array}{l}-0.03 \\
(0.06)\end{array}$ \\
\hline Share foreign population 2017 (\%) & $\begin{array}{l}-0.12 \\
(0.44)\end{array}$ & $\begin{array}{c}0.33 \\
(0.62)\end{array}$ & $\begin{array}{c}0.01 \\
(0.01)\end{array}$ & $\begin{array}{l}-0.01 \\
(0.02)\end{array}$ \\
\hline$\Delta$ Share foreign pop 2012-17 (\%) & $\begin{array}{l}-0.53 \\
(0.74)\end{array}$ & $\begin{array}{c}0.56 \\
(1.27)\end{array}$ & $\begin{array}{l}-0.01 \\
(0.02)\end{array}$ & $\begin{array}{l}-0.00 \\
(0.03)\end{array}$ \\
\hline Unemployment rate 2019 (\%) & $\begin{array}{l}-0.10 \\
(0.29)\end{array}$ & $\begin{array}{l}1.16^{*} \\
(0.48)\end{array}$ & $\begin{array}{c}0.01 \\
(0.01)\end{array}$ & $\begin{array}{l}-0.01 \\
(0.01)\end{array}$ \\
\hline$\Delta$ Unemployment rate 2013-19 (\%) & $\begin{array}{c}0.01 \\
(0.42)\end{array}$ & $\begin{array}{l}-0.04 \\
(0.40)\end{array}$ & $\begin{array}{l}-0.01 \\
(0.01)\end{array}$ & $\begin{array}{c}0.01 \\
(0.01)\end{array}$ \\
\hline Aged 60 or above 2017 (\%) & $\begin{array}{l}-0.21 \\
(0.34)\end{array}$ & $\begin{array}{l}-0.27 \\
(0.70)\end{array}$ & $\begin{array}{l}-0.01 \\
(0.01)\end{array}$ & $\begin{array}{l}-0.00 \\
(0.01)\end{array}$ \\
\hline$\Delta$ Aged 60 or above $2012-17(\%)$ & $\begin{array}{c}0.36 \\
(0.92)\end{array}$ & $\begin{array}{c}1.30 \\
(1.63)\end{array}$ & $\begin{array}{c}0.02 \\
(0.02)\end{array}$ & $\begin{array}{c}0.02 \\
(0.03)\end{array}$ \\
\hline Nr of employees 2017 (1k) & $\begin{array}{c}0.85 \\
(0.56)\end{array}$ & $\begin{array}{c}7.49 \\
(6.10)\end{array}$ & $\begin{array}{c}0.18 \\
(0.10)\end{array}$ & $\begin{array}{c}0.00 \\
(0.02)\end{array}$ \\
\hline$\Delta \mathrm{Nr}$ of employees 2012-17 (1k) & $\begin{array}{l}-1.84 \\
(1.82)\end{array}$ & $\begin{array}{c}-24.29 \\
(19.50)\end{array}$ & $\begin{array}{l}-0.49 \\
(0.33)\end{array}$ & $\begin{array}{c}0.10 \\
(0.10)\end{array}$ \\
\hline Intercept & $\begin{array}{r}54.99^{*} \\
(9.52) \\
\end{array}$ & $\begin{array}{c}71.42^{*} \\
(18.72) \\
\end{array}$ & $\begin{array}{l}0.97^{*} \\
(0.33) \\
\end{array}$ & $\begin{array}{c}0.77^{*} \\
(0.35) \\
\end{array}$ \\
\hline $\mathrm{N}$ & 509 & 232 & 225 & 332 \\
\hline R2 & 0.24 & 0.20 & 0.26 & 0.26 \\
\hline
\end{tabular}




\section{Auxiliary information}

\section{D.1 The prime minister's approval ratings}

Figure A3: Approval ratings for Bavaria's prime minister before and after the elections of 15 March 2020

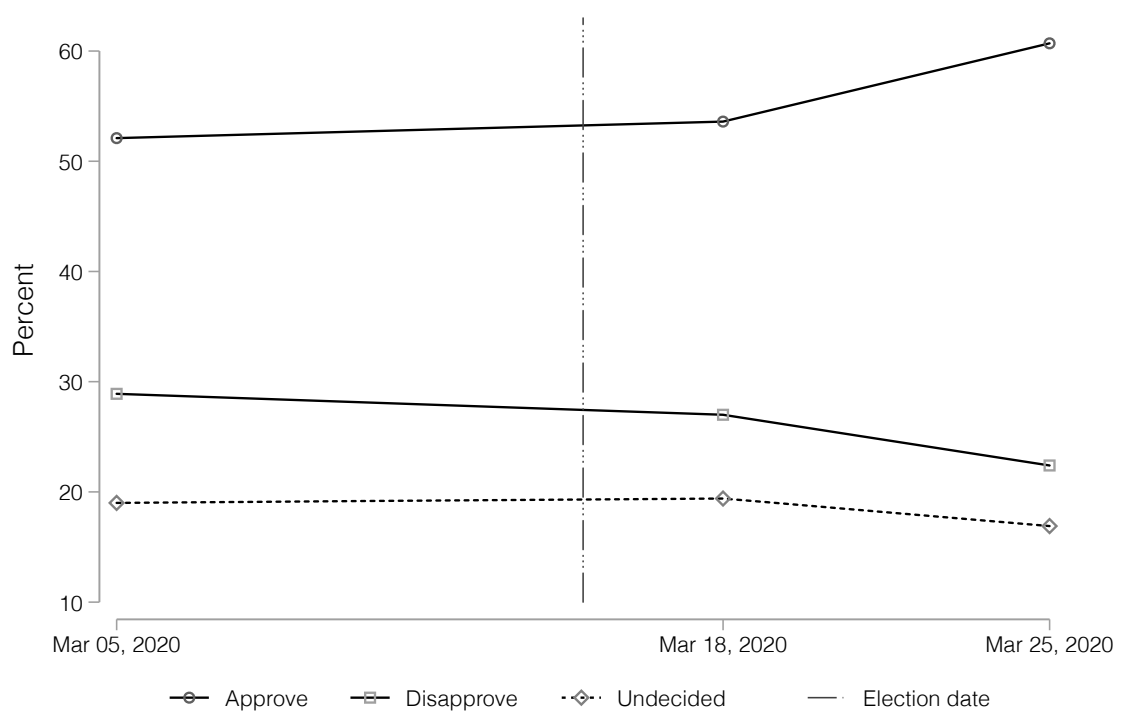

Note: The figure shows the approval ratings for Bavaria's prime minister (Ministerpräsident) Markus Söder for three points in time. The first comes from 5 March 2020, shortly before the period for which COVID-19 data is available; the second from 18 March 2020, shortly after the first round of the communal elections; and the third from 25 March, ten days after the first round of the elections, during which the pandemic started to escalate. The vertical line indicates the date of the election (15 March 2020). BR-BayernTrend, data collected by infratest dimap for Bayrischer Rundfunk, $\mathrm{n} \sim 1,000 /$ poll, Source: https: / / www.br.de/nachrichten/br-bayerntrend-umfrage-archiv,RESSyRW, last checked on 04/01/2020. 